\title{
Rapid transitions in the Atlantic thermohaline circulation triggered by global warming and meltwater during the last deglaciation
}

\author{
Gregor Knorr \\ School of Earth, Ocean and Planetary Sciences, Cardiff University, Cardiff CF10 3YE, UK (knorrg@cardiff.ac.uk)
}

\section{Gerrit Lohmann, Alfred Wegener Institute for Polar and Marine Research, Bussestrasse 24, D-27570 Bremerhaven, Germany}

[1] In a series of sensitivity experiments, using a three-dimensional ocean general circulation model, rapid climate shifts during the last deglaciation are interpreted in terms of gradual temperature changes and freshwater perturbations, which impact on the Atlantic thermohaline circulation (THC). We show that increasing global temperature leads to a rapid intensification of the THC. The transition to an interglacial THC mode is preconditioned by a decrease of the subsurface temperatures due to an increase in ventilation of the subsurface water in the northern North Atlantic, which enhances the merdional transport of salt to the northern high latitudes and gradually erodes the halocline. This process enables the remaining temperature inversion to overcome the salinity stratification in the northern North Atlantic, which causes a kick start of vigorous convection and a rapid intensification of the Atlantic THC. As a result of the abrupt THC amplification and the deglacial warming and sea ice retreat in the Southern Ocean, enhanced transport of relatively salty surface and intermediate-depth waters from the Indian Ocean provides an additional source of salt to the North Atlantic, which changes the stability behavior of the THC with respect to freshwater perturbations. A warming-induced transition from a weak glacial THC to a stronger THC state, with different North Atlantic freshwater hysteresis characteristics, provides a concept that might explain the sequence of events, characterizing the last glacial termination as recorded in proxy data.

Components: 13,866 words, 13 figures, 1 table.

Keywords: deglaciation; thermohaline circulation; rapid climate change; climate modeling; thermohaline circulation stability; Termination I.

Index Terms: 4901 Paleoceanography: Abrupt/rapid climate change (1605); 4928 Paleoceanography: Global climate models (1626, 3337); 4962 Paleoceanography: Thermohaline.

Received 7 February 2007; Revised 20 September 2007; Accepted 11 October 2007; Published 20 December 2007.

Knorr, G., and G. Lohmann (2007), Rapid transitions in the Atlantic thermohaline circulation triggered by global warming and meltwater during the last deglaciation, Geochem. Geophys. Geosyst., 8, Q12006, doi:10.1029/2007GC001604.

\section{Introduction}

[2] Ice core records exhibit that deglacial warming at the transition from the last glacial period to the present interglacial, the Holocene, started at $\sim 20 \mathrm{ka}$ B.P. (thousand years before present) [Blunier et al., 1997; Alley et al., 2002]. Changes in atmospheric $\mathrm{CO}_{2}$ and Vostok air temperature occurred nearly 
coincidentally, whereas ice volume lags these variables as revealed by cross-spectral analyses [Shackleton, 2000]. It has been suggested that increasing atmospheric $\mathrm{CO}_{2}$ concentration contributed to global deglacial warming [Arrhenius, 1896; Bender et al., 1997]. Different feedbacks, involving, e.g., ice albedo and greenhouse-gas effects, caused regional to global synchronization of deglaciation [Alley and Clark, 1999]. In response to global warming, freshwater discharge from the huge northern ice sheets to the North Atlantic may have shut down the THC [Stocker and Wright, 1991; McCabe and Clark, 1998]. Therefore reduced northward oceanic heat transport maintained cold conditions, lasting from $\sim 17.5 \mathrm{ka}$ B.P. to $\sim 14.7$ ka B.P. [e.g., Sarnthein et al., 1994; McManus et al., 2004; Knutz et al., 2007], while in the Southern Hemisphere the deglacial warming trend proceeded, as documented by alkenone and oxygen isotope based sea surface temperature (SST) records from the Cape Basin [Sachs et al., 2001], as well as of the Brazilian and Namibian coasts [Arz et al., 1999; Kim et al., 2002]. The end of the Northern Hemisphere cold sequence, associated with Heinrich event 1 (H1) [Heinrich, 1988], is marked by the abrupt transition to the Bølling/Allerød (B/A) warm phase in Greenland and the North Atlantic at $\sim 14.7$ ka B.P. [Grootes et al., 1993; Sarnthein et al., 1994; Waelbroeck et $a l ., 2001]$. At the same time temperatures in Antarctica decrease and the onset of the Antarctic cold reversal (ACR) is detected [Blunier and Brook, 2001; EPICA Community Members, 2006]. During the $\mathrm{B} / \mathrm{A}$, temperatures in the North Atlantic reached almost interglacial values, which is consistent with intensified North Atlantic Deep-Water (NADW) formation, as corroborated by benthic $\delta^{13} \mathrm{C}$ data [e.g., Sarnthein et al., 1994], ${ }^{14} \mathrm{C}$ ventilation ages [e.g., Skinner and Shackleton, 2004] and ${ }^{231} \mathrm{~Pa} /{ }^{230} \mathrm{Th}$ ratios of marine bulk sediments [McManus et al., 2004; Gherardi et al., 2005]. A major inflow of meltwater to the ocean, referred to as meltwater pulse 1A (MWP-1A) [Fairbanks, 1989], accompanied the shift to warmer conditions in the North Atlantic. Surprisingly, NADW formation did not cease immediately and the next significant cooling probably related to a THC shutdown, occurred more than 1000 a later at the onset of the Younger Dryas (YD) [e.g., Stanford et al., 2006]. Finally, the YD ends at $\sim 11.5$ ka B.P. and North Atlantic realm again experiences a strong warming [Severinghaus et al., 1998].

[3] The abrupt $\mathrm{B} / \mathrm{A}$ warming has raised some debate regarding the timing of deglaciation in the
Northern versus Southern Hemispheres. Some workers [e.g., Sowers and Bender, 1995; Petit et al., 1999] interpreted the $\mathrm{B} / \mathrm{A}$ as the onset of deglacial warming over Greenland, while reanalysis of ice core data has been interpreted to show a warming of approximately one-third of the total termination I warming over almost $10 \mathrm{ka}$ prior to the onset of the B/A [Alley et al., 2002]. The correlation between the Byrd and GISP2 ice core chronologies based on the isotopic composition of $\delta^{18} \mathrm{O}_{\text {atm }}$ of $\mathrm{O}_{2}$ in air bubbles also yields a northern lead for the onset of warming [Bender et al., 1999]. The latter interpretation is in accordance with the Milankovitch [Milankovitch, 1941] theory. A key element of this theory is that summer insolation at high latitudes in the Northern Hemisphere determines glacial-interglacial transitions connected with the waxing and waning of large continental ice sheets [e.g., Imbrie and Imbrie, 1980].

[4] Modeling investigations have suggested that changes in the Southern Hemisphere are able to trigger an abrupt amplification of the THC. In one scenario gradual warming and receding sea-ice cover around Antarctica leads to an abrupt amplification of the THC [Knorr and Lohmann, 2003], by increased mass transport into the Atlantic Ocean via the warm (Indian Ocean) and the cold water route (Pacific Ocean) [Gordon, 1986; Gordon et al., 1992] of the global ocean circulation.

[5] Deglacial global warming can affect the THC by surface warming and surface freshening associated to melting ice sheets. Both forcing factors reduce the density of high-latitude surface waters and thus inhibiting NADW formation. Given the promotion of such conditions during deglacial climate change it would appear contradictory to a THC intensification at the B/A onset. Furthermore, the surprising climate response to the MWP-1A seems to make clear that the THC and climate cannot be simply controlled by the magnitude or rate of meltwater discharge.

[6] Therefore we here examine the impact of gradual global warming on the Atlantic THC using a three-dimensional ocean general circulation model. Initially focus is given to the simulation of the sequence from the Last Glacial Maximum (LGM) ( 20 ka B.P.) until the B/A, including different meltwater scenarios in order to understand the mechanisms and processes that control deglacial THC changes. On the basis of the LGM - B/A sequence, we then investigate changes in the stability behavior of the THC with respect to gradual changing climate background conditions and North 
Atlantic freshwater perturbations. The respective analyzes of the different equilibrium states is a key element for an understanding of the climate sequence including the $\mathrm{B} / \mathrm{A}, \mathrm{YD}$ and the Holocene.

[7] A further aspect of this study is to investigate changes in the spatiotemporal temperature pattern in the Atlantic in response to THC shifts in order to address the question of an apparent lead of increasing Southern Hemisphere temperatures, relative to Greenland temperatures during deglaciation.

\section{Methodology}

[8] The three-dimensional ocean general circulation model is based on the large-scale geostrophic model (LSG) [Maier-Reimer et al., 1993]. The horizontal resolution is $3.5^{\circ}$ on a semi-staggered grid (type "E") with 11 levels in the vertical. The model includes a simple thermodynamic sea ice model, a 3rd order advection scheme for temperature and salinity [Schäfer-Neth and Paul, 2001], and a parameterization of overflow [Lohmann, 1998; Lohmann and Schulz, 2000]. For glacial conditions the storage of water in inland ice sheets is taken into account by setting all ocean points with present-day water depth less than $120 \mathrm{~m}$ to land. This causes the Bering Strait to be closed and shallow areas like the Arctic shelves to become land. The ocean is driven by monthly fields of wind stress, surface air temperature and freshwater flux, which are taken from a present-day and a LGM simulation of the atmospheric general circulation model ECHAM3/T42 [Roeckner et al., 1992; Lohmann and Lorenz, 2000]. In order to close the hydrological cycle, a runoff scheme transports freshwater from the continents to the ocean. We employ a modeling approach, which allows an adjustment of surface temperatures and salinity to changes in the ocean circulation, based on an atmospheric energy balance model. In the model, sea surface salinity can freely evolve. The heat flux exchange $\mathrm{Q}$ at the ocean surface is formulated as suggested by Rahmstorf and Willebrand [1995]:

$$
\mathrm{Q}=\left(\lambda_{1}-\lambda_{2} \nabla^{2}\right) \cdot\left(\mathrm{T}_{\mathrm{a}}-\mathrm{T}_{\mathrm{s}}\right)
$$

where $T_{a}$ is the prescribed air temperature, and $T_{s}$ denotes the ocean surface temperature. The heattransfer coefficients $\lambda_{1}$ and $\lambda_{2}$ are chosen to be $15 \mathrm{~W} \mathrm{~m}^{-2} \mathrm{~K}^{-1}$ and $2 \times 10^{12} \mathrm{~W} \mathrm{~K}^{-1}$, respectively. The applied heat flux parameterization has shown to be a suitable choice, allowing the simulation of observed SSTs and the maintenance of large-scale temperature anomalies in perturbation experiments [Prange et al., 2003].

[9] For the present-day state, we obtain a THC with a NADW export of $14 \mathrm{~Sv}\left(1 \mathrm{~Sv}=10^{6} \mathrm{~m}^{3} \mathrm{~s}^{-1}\right)$ at $30^{\circ} \mathrm{S}$ and maximum heat transport of $1.1 \mathrm{PW}$, which is in the range of observations [Macdonald and Wunsch, 1996]. For the LGM, our modeled ocean circulation is characterized by a weaker circulation, which is in agreement with proxy data [e.g., Lynch-Stieglitz et al., 2007]. The overturning circulation in the Atlantic can be characterized by a NADW export of $8.5 \mathrm{~Sv}$ and southward shifted convection sites compared to present-day sites [Prange et al., 2002; Knorr and Lohmann, 2003]. NADW is formed in the sub-polar North Atlantic and the North Atlantic Current flows in a zonal direction along the horizontal density gradients, consistent with reconstructions [e.g., Sarnthein et al., 1994]. A detailed description of the modern THC and hydrographic fields can be found elsewhere [Prange et al., 2003; Romanova et al., 2004].

\section{Experimental Setup}

\subsection{LGM-B/A Interval}

[10] The investigations in this study consist of two main parts. In the first section we simulate the deglacial climate sequence between the LGM and the $\mathrm{B} / \mathrm{A}$ (experiments $\mathrm{B} 1-\mathrm{B} 4)$ ). In the second part of this study we perform a stability analysis of the resulting THC mode, with respect to slowly varying changes in the background climate and freshwater input to the North Atlantic.

[11] The deglaciation is implemented in the model by a linear transition from global glacial to interglacial background climate conditions in temperature, sea ice in the Southern Ocean and wind stress. The respective changes at each grid point are prescribed according to a linear trend between its glacial and its interglacial value, which gives rise to a linear progression between two temperature, sea ice and wind stress distributions. The freshwater fluxes remain constant in glacial conditions in order to isolate the deglacial temperature and meltwater impact on the THC. For a more detailed description of the forcing fields we would like to refer to Lohmann and Lorenz [2000]. The model forcing at a certain time is given by

$$
\text { Climate Forcing }=\mathrm{LGM}+(\mathrm{PD}-\mathrm{LGM}) \cdot \mathrm{t} / \mathrm{T}
$$


Table 1. Different North Atlantic Freshwater Inflow Characteristics of Experiments B1-B4 as Chosen for the LGM-B/A Interval ${ }^{\mathrm{a}}$

\begin{tabular}{cccc}
\hline & $\begin{array}{c}\text { Background Flow } \\
\text { After 19 ka B.P., } \\
\text { Evperiment }\end{array}$ & $\begin{array}{c}\text { H1a/H1b, } \\
\text { Sv }\end{array}$ & $\begin{array}{c}19 \text { ka MWP, } \\
\text { Sv }\end{array}$ \\
\hline B1 & - & - & - \\
B2 & 0.05 & - & - \\
B3 & 0.05 & $0.15 / 0.15$ & - \\
B4 & 0.05 & $0.15 / 0.15$ & 0.25 \\
\hline
\end{tabular}

${ }^{\mathrm{a}}$ See also Figure 1a.

where LGM and PD are glacial and pre-industrial interglacial climate background conditions, $t$ the integration time in model years and $\mathrm{T}$ the time of a full glacial to interglacial transition. We haven chosen $\mathrm{T}=15,000 \mathrm{a}$, which has been motivated by long-term temperature trends as recorded in ice cores from Greenland and Antarctica during termination I [e.g., Sowers and Bender, 1995; Petit et al., 1999; Alley et al., 2002]. In the Northern Hemisphere the ocean model includes a simple thermodynamic sea ice model [Lohmann and Gerdes, 1998]. The modeling approach with a thermodynamic sea ice model in the Northern Hemisphere and prescribed sea ice in the Southern Ocean has been chosen because of the different deglacial temperature evolution recorded by Greenland and Antarctic ice cores. The deglacial temperature evolution in Greenland and in the North Atlantic is characterized by a sequence of rapid climate shifts, while the glacial age temperature variability recorded by Antarctic ice cores is characterized by a more gradual behavior, representing increasing temperatures in the interval between the LGM and the B/A. Therefore we assume for simplicity that long term changes in Southern Ocean sea ice cover are dominated by impact of deglacial global warming. In contrast the climate and probably sea ice cover, in the northern North Atlantic in the same interval is dominated by large-scale changes in the Atlantic THC, as suggested by marine proxy data. To account for this difference the model includes a thermodynamic sea ice model in the Northern Hemisphere, while changes in Southern Ocean sea ice cover have been prescribed according to the temperature changes. In the Southern Hemisphere sea surface temperatures are set to the freezing point when grid cells are covered by sea ice or when surface temperatures fall below the freezing point because of strong surface heat losses.

[12] In our deglacial scenarios B1-B4 the climate forcing is held constant after 7000 model years in order to obtain an equilibrium climate state. The gradual warming of 7000 a is related to $13 \mathrm{ka}$ B.P. on a geological timescale, i.e., $7 / 15(\sim 47 \%)$ of the total termination I warming. In addition to the gradually changed background climate in experiment B1, further experiments with various freshwater flux perturbations to the North Atlantic have been conducted to mimic the effect of melting ice from the Laurentide and Fennoscandian Ice Sheets. On the basis of geological evidence potential meltwater pulses have been suggested to occur at 19 ka B.P. (19 ka MWP) [Clark et al., 2004], 17.5 ka B.P. (H1b) and 16 ka B.P. (H1a) [Bard et al., 2000]. Although, the existence of a significant meltwater pulse at $19 \mathrm{ka}$ has recently been challenged on the basis of an extended set of observations of the postglacial history of sea level rise at Barbados [Peltier and Fairbanks, 2006].

[13] Our scenarios range from conservative meltwater input in B2 to more radical reconstructions including several distinct meltwater pulses in B4. In experiment B2, we apply a constant meltwater inflow of $0.05 \mathrm{~Sv}$ starting after 1000 model years. This starting point of meltwater inflow is related to $19 \mathrm{ka}$ B.P. on a geological timescale, since ice volumes approached their maximum values $\sim 30 \mathrm{ka}$ ago and remained nearly constant until $19 \mathrm{ka}$ ago, which defines the period of maximum global glaciation [Lambeck et al., 2002]. In experiment B3 we include the Heinrich meltwater pulses H1a and H1b. In addition to these Heinrich meltwater pulses we apply the 19 ka MWP in experiment B4. The 19 ka MWP is simulated by a freshwater-flux magnitude of $0.25 \mathrm{~Sv}$ [Clark et al., 2004] with a duration of 200 a. Both Heinrich pulses $\mathrm{H1a}$ and $\mathrm{H} 1 \mathrm{~b}$ are performed with a 400 a freshwater release of $0.15 \mathrm{~Sv}$ centered at 17.5 and $16 \mathrm{ka}$. The values agree with estimates of deglacial meltwater release, related to the Heinrich pulses, as assessed in different studies [e.g., Dowdeswell et al., 1995; Hemming, 2004]. The deglacial background meltwater discharge of 0.05 $\mathrm{Sv}$ is applied throughout the remaining time of experiment B3 and B4 analogous to B2 between 1000 and 8000 model years.

[14] The resulting sea level rise in the first 5500 model years, related to a geological time interval between the LGM ( $\sim 20 \mathrm{ka}$ B.P.) and the B/A ( $\sim 14.5 \mathrm{ka}$ B.P.), is $\sim 20 \mathrm{~m}(\mathrm{~B} 2), \sim 27 \mathrm{~m}(\mathrm{~B} 3)$ and $\sim 30 \mathrm{~m}$ (B4). These sea level changes are within the range of data based estimates [e.g., Hanebuth et al., 2000; Lambeck et al., 2002; Peltier and Fairbanks, 2006]. All deglacial meltwater discharge to the 
A

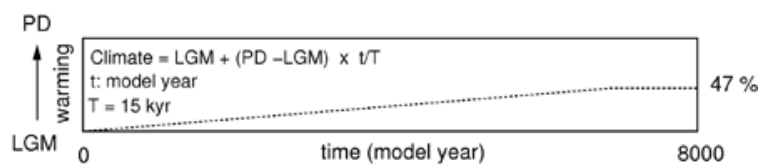

B

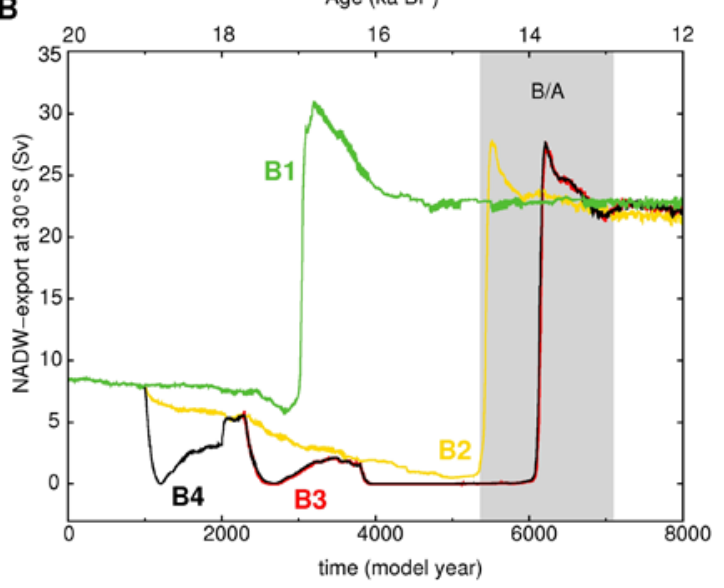

Figure 1. Schematic illustration of changes in the climate background forcing and model response of the NADW export. (a) The background climate conditions are linearly interpolated between glacial (LGM) and modern (PD) conditions. All experiments start from the glacial equilibrium. Gradual warming is stopped after 7000 model years, which is related to $7 / 15(\sim 47 \%)$ of the total termination I warming. (b) NADW export at $30^{\circ} \mathrm{S}$ versus time. The green curve (B1) represents the experiment without any deglacial freshwater release to the North Atlantic. Experiments B2 (yellow curve), B3 (red curve), and B4 (black curve) exhibit different successions of deglacial meltwater pulse scenarios to the North Atlantic (see Table 1).

North Atlantic is uniformly distributed between $20^{\circ} \mathrm{N}$ and $50^{\circ} \mathrm{N}$. This meltwater distribution has been chosen to enable a comparison of the transient model behavior to abrupt meltwater events into the framework of the quasi-equilibrium hysteresis analysis described in the following section 3.2. To validate this approach we have examined the sensitivity of the glacial equilibrium state to different meltwater routing as documented in Appendix A. The different experiment characteristics of B1-B4 are summarized in Table 1.

\subsection{Stability Analysis of the THC}

\subsubsection{Gradual Changes of the Background Climate}

[15] In order to comprehend changes in the THC in response to deglacial warming in more detail we investigate the stability of the THC with respect to gradual changes in the background climate. This is necessary to understand the qualitative behavior of the THC in dependence on the initial climate conditions. To aim this we gradually change the climate background conditions identically to the imposed alterations in experiment B1. After $5000 \mathrm{a}$, i.e., one third of a full glacial to interglacial transition, the linear changes in the temperature, sea ice and wind stress fields are reversed and the model is integrated for another 5000 a until the background climate is again at full glacial conditions. The resulting overturning response can be interpreted as the oceanic hysteresis to deglacial climate change.

\subsubsection{Freshwater Perturbations}

[16] The qualitative behavior of the ocean circulation is analyzed for the $\mathrm{B} / \mathrm{A}$ interstadial with a relatively strong THC compared to the glacial mode with weak overturning. In a hysteresis analysis we examine the THC stability with respect to North Atlantic freshwater discharge based on experiment B4 after 8000 model years. We apply a slowly varying freshwater anomaly with a rate of $5 \times 10^{-5} \mathrm{~Sv} \mathrm{a}^{-1}$ in the North Atlantic. Integration starts with a deglacial background meltwater flux of $0.05 \mathrm{~Sv}$ that increases to $0.35 \mathrm{~Sv}$. Subsequently, the freshwater input is decreased until $-0.35 \mathrm{~Sv}$, and then again increased to $0.05 \mathrm{~Sv}$ to close the loop. Given the rate of change the experiment requires a total integration length of 28,000 model years. The freshwater perturbation is uniformly applied between $20^{\circ} \mathrm{N}$ and $50^{\circ} \mathrm{N}$. This changes the large-scale freshwater balance of the North Atlantic, without forcing the high latitude convection regions directly. The freshwater flux is not compensated elsewhere. Due to the slowly varying nature of the surface forcing the model is in quasiequilibrium during the integration except during mode transitions [cf. Rahmstorf, 1995].

\section{Results}

\subsection{LGM-B/A Interval}

[17] Related to the deglacial warming (Figure 1a), experiments B1-B4 clearly exhibit a rapid transition from a weak glacial to a stronger interglacial like THC within $\sim 100$ a (Figure $1 \mathrm{~b}$ ). The simulations show that the timing of the transition partly depends on the imposed freshwater input into the North Atlantic. Compared to B1, the abrupt overturning amplification in the meltwater scenarios B2, B3, and B4 is delayed in time (Figure 1b). In experiment $\mathrm{B} 1$ and $\mathrm{B} 2$ the rapid intensification of 


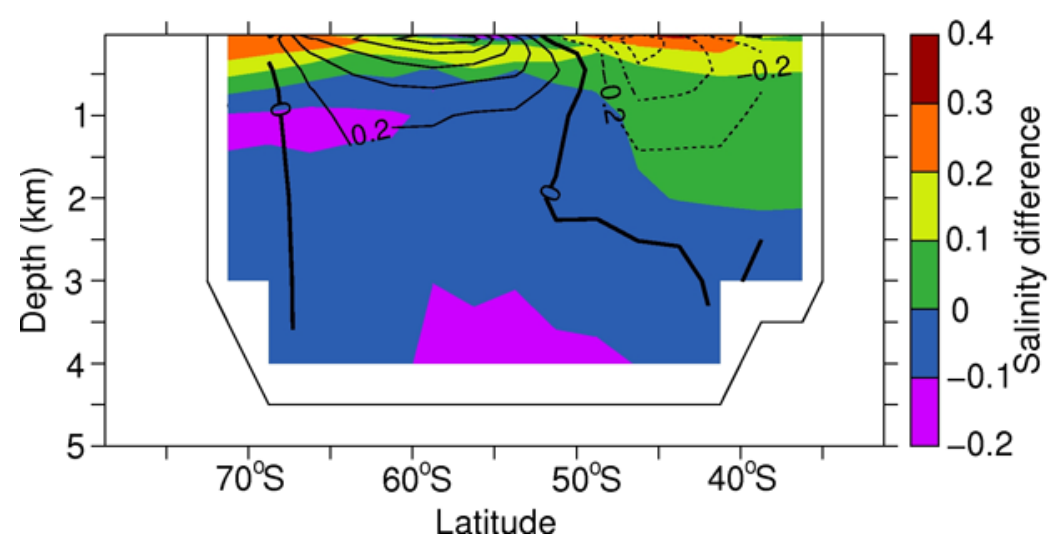

Figure 2. Differences in the annual mean zonal velocity component $\left(\mathrm{cm} \mathrm{s}^{-1}\right)$ and salinity (psu) between experiment B1 after 2500 model years and the LGM equilibrium state. Solid contours indicate anomalous eastward velocities; dashed contours represent anomalous westward velocities. The meridional profile is along $20^{\circ} \mathrm{E}$, representing a vertical cross section between South Africa and Antarctica.

the THC occurs after $\sim 3000$ and $\sim 5300$ model years, respectively. These time intervals are related to a warming of $\sim 1 / 5$ and $\sim 1 / 3$ of the total termination I warming. The rapid THC amplification in B3 and B4 is detected in both experiments after $\sim 6000$ model years, which is related to $\sim 2 / 5$ of the total termination I warming. Furthermore it can be seen that the rapid THC intensification is independent of a potential meltwater perturbation at $19 \mathrm{ka}$ B.P. as shown by the synchronous temporal evolution of the NADW export after 2000 model years in B3 and B4.

[18] The abrupt THC intensification can occur from states with both weak and absent NADW export at $30^{\circ} \mathrm{S}$. These states of circulation in the Atlantic are in the following referred to as the THC "on" mode and the THC "off" mode. During the phase prior to the rapid THC amplification different effects influence NADW formation. In experiment B1 (where the deglacial warming without superimposed freshwater perturbations is applied) primarily gradual warming reduces the density of surface waters, which tend to weaken NADW formation. This effect is even stronger in B2-B4 where additional freshening has been applied.

[19] As a stabilizing effect, the gradual warming and sea ice retreat in the Southern Ocean favors the conveyance of relatively saline water masses from the Indian Ocean into the Atlantic as part of the global ocean circulation. The warming induces anomalous westward and eastward velocities north and south of $\sim 50^{\circ} \mathrm{S}$, respectively (Figure 2 ). The strongest increase in salinity exceeding $0.3 \mathrm{psu}$ occurs within the core of the anomalous westward velocity component, which is associated with a reduced eastward transport south of the subtropical convergence and an enhanced inflow of relatively salty water from the Indian Ocean. These transport changes precondition NADW formation and increase convective activity in the North Atlantic, which counteracts the weakening impact of warming and sea ice melting in the North Atlantic on the THC. Therefore the THC strength is stabilized during the first 2500 model years in B1 (Figure 1b).

[20] The deglacial evolution of THC changes in experiments B2, B3 and B4 represent a combined THC response to global warming and freshwater forcing. The meltwater inflow additionally reduces the surface salinity and hence the density in the deep-water formation regions. Therefore the high latitude freshening weakens NADW formation and decreases the THC strength in B2-B4 (Figure 1b). Subsequently, global warming leads to a rapid intensification of the THC in all experiments.

\subsection{Experiment B4}

[21] In the following we focus on experiment B4, which includes the simulation of the 19 ka MWP [Clark et al., 2004], as well as the Heinrich meltwater pulses H1a and H1b [Bard et al., 2000]. We have decided to analyze deglacial scenario B4 in order to understand a history of potential deglacial events and their effect on the THC dynamics. Details of the model response in B4 are shown in Figures 2-8. Figure 3 displays time series of sea surface salinity and temperature changes in the North and South Atlantic. Figure 4 depicts the deglacial time evolution of the meridional stream function in the Atlantic. Figures 5, 6, 

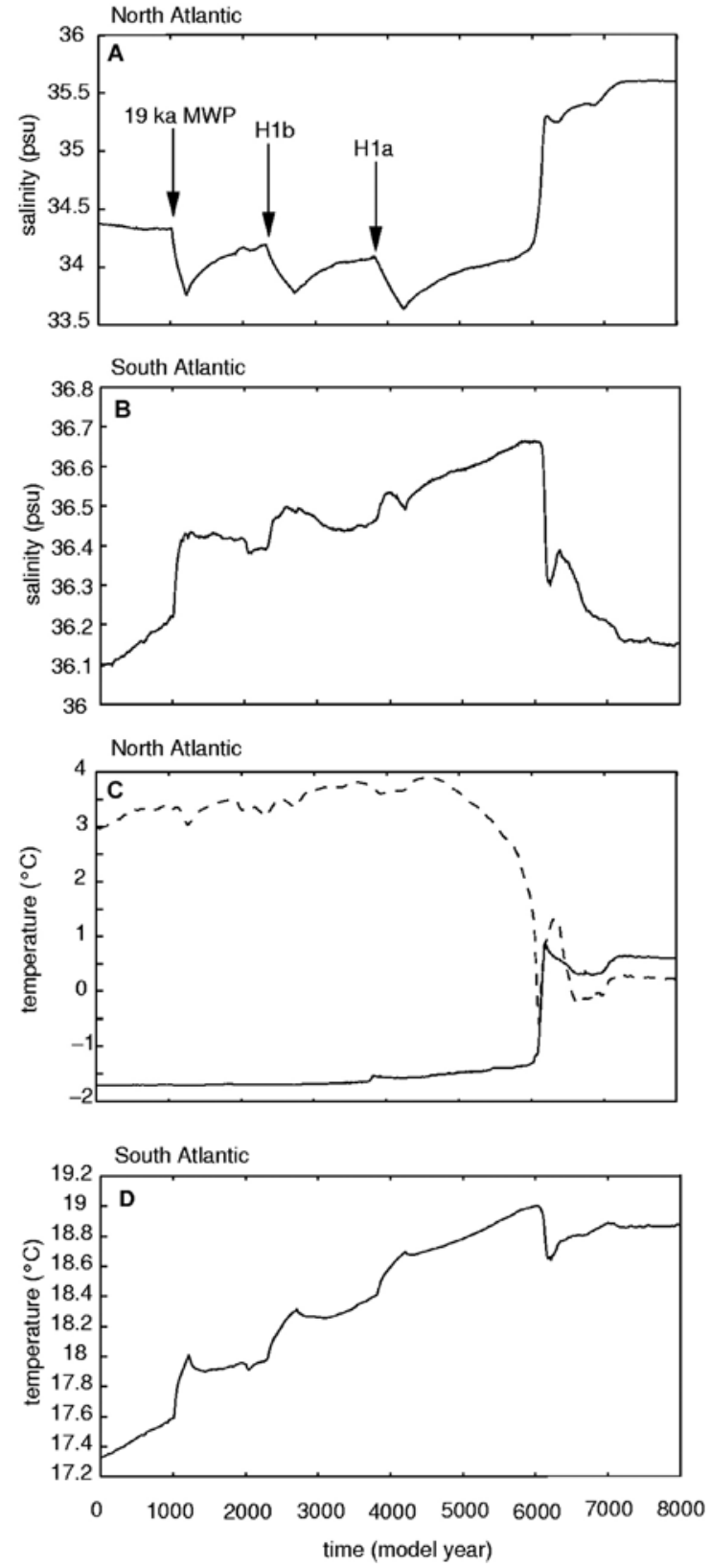

Figure 3. Temporal salinity and temperature changes in the Atlantic Ocean in experiment B4. Figures 3a and $3 \mathrm{~b}$ show averaged North Atlantic $\left(65^{\circ}-75^{\circ} \mathrm{N}\right)$ and South Atlantic $\left(20^{\circ}-30^{\circ} \mathrm{S}\right)$ salinity changes in the upper $100 \mathrm{~m}$. Figures $3 \mathrm{c}$ and $3 \mathrm{~d}$ show the respective SST changes $\left({ }^{\circ} \mathrm{C}\right)$. Additionally, the averaged subsurface temperature in the North Atlantic between $850 \mathrm{~m}$ and $1500 \mathrm{~m}$ (dashed curve) is shown in Figure 3c. The arrows mark the onset of the meltwater pulses.

and 7 show spatial temperature signatures and changes in the near-surface Atlantic flow fields in response to the $19 \mathrm{ka}$ MWP, H1a and the abrupt resumption of the Atlantic THC after $\sim 6000$ model years. Figure 8 shows characteristic salinity changes in the Atlantic linked to the THC amplification.

[22] Experiment B4 shows that the THC reduces immediately in response to the $19 \mathrm{ka}$ MWP (Figure 1b), as decreasing salinity (Figure 3a) and hence density in the North Atlantic surface layer additionally weakens NADW formation. The decrease of salinity in the near-surface North Atlantic is amplified by a positive feedback owing to reduced salinity advection from the tropical Atlantic. Conversely, the THC slowdown and reduced northward salinity advection increases salinity in the tropical and subtropical South Atlantic (Figure 3b). The 19 ka MWP, as well as the H1a and $\mathrm{H} 1 \mathrm{~b}$ meltwater events cause a cessation of NADW export (Figure 1b). The 19 ka MWP generates a temporary shut down of THC and the overturning circulation recovers as the meltwater inflow decreases. After the meltwater perturbation H1a, the NADW export out of the Atlantic remains halted (Figure 1b). The THC "off" mode prevails until the resumption of the Atlantic THC. Although convective activity is considerably reduced during the THC "off" mode, a weak and shallow overturning cell in the tropical and subtropical North Atlantic is maintained (Figure 4a). This cell mainly consists of a wind driven surface Ekman transport to the north, which is compensated by the southward ventilation of extra-tropical surface water with upwelling at the equator (Figure 4a). The volume transport in this cell is mainly due to the surface Ekman transport. Moreover the wind driven circulation is important, since the main portion of freshwater export from the northern North Atlantic is assigned to the anticyclonic North Atlantic gyre circulation. The associated transports primarily govern the oceanic conveyance of heat and salt in the North Atlantic during the THC "off" mode.

[23] In response to the 19 ka MWP the flow field and temperature distribution in the near-surface Atlantic change within decades. After 1200 model years at the end of the 19 ka MWP, when NADW export stops (Figure 1b), a modified circulation is directly linked to changes in oceanic heat transports and hence temperature distribution in the Atlantic (Figure 5a). In the near-surface Atlantic Ocean the slowdown of the THC is characterized by an overall anomalous southward flow of water (Figure 5a). The consequence is a surface warming in large parts of the South Atlantic and a cooling in the North Atlantic. This temperature pattern is also prominent in the intermediate and deeper layers of the Atlantic Ocean (Figure 5b). 


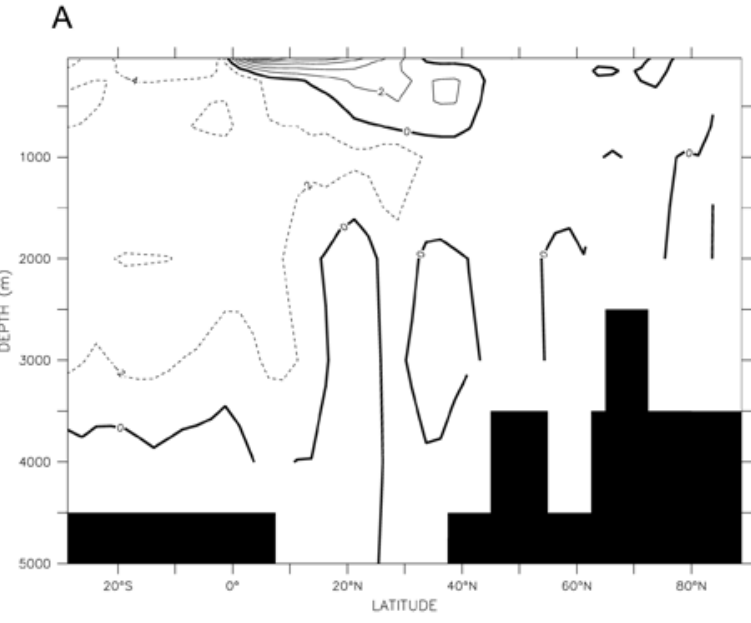

C
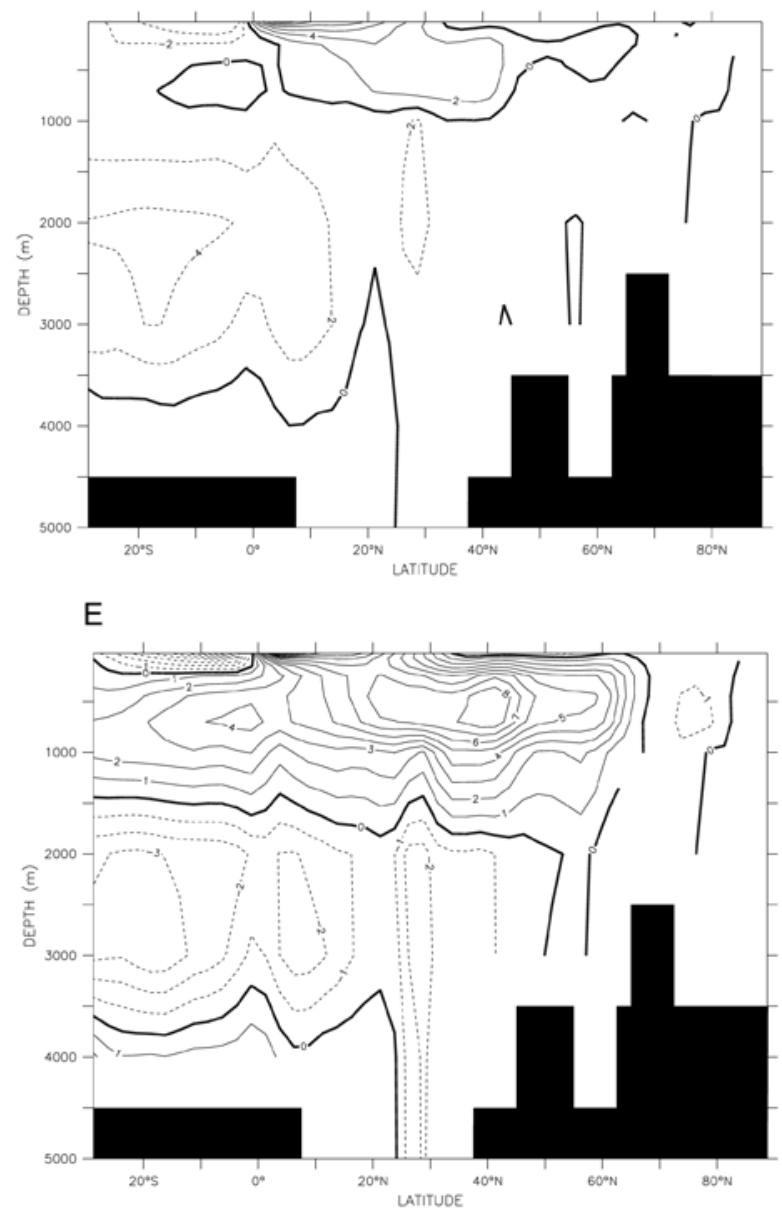

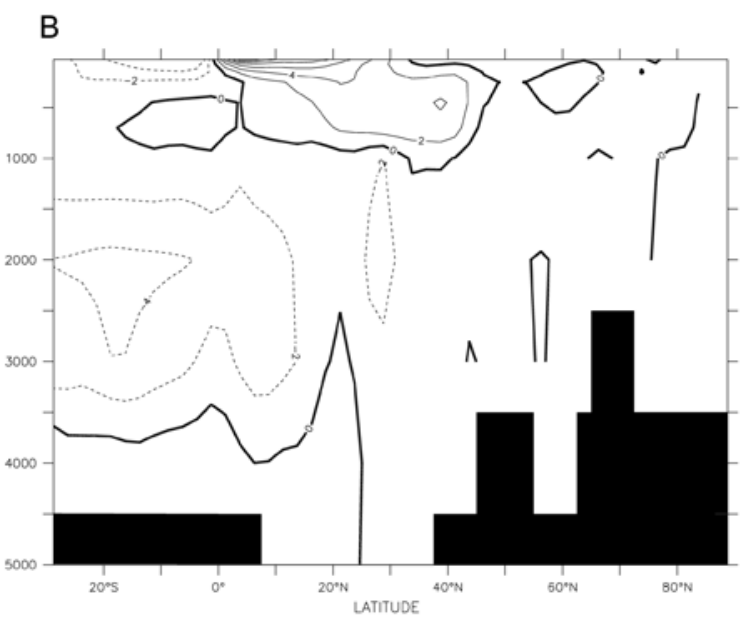

D
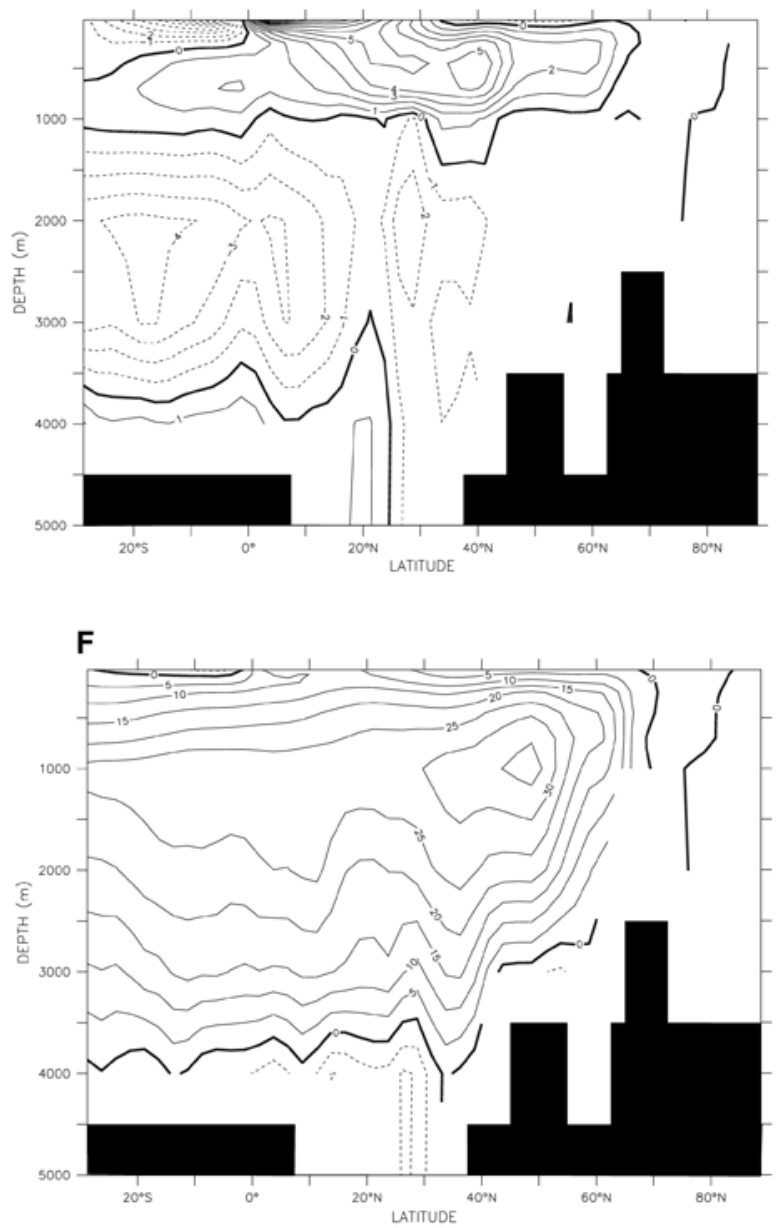

Figure 4. Meridional overturning stream functions (10-a mean) in the Atlantic basin at different times during deglaciation, after (a) 4200, (b) 5700, (c) 5800, (d) 6050, (e) 6100, and (f) 6200 model years in experiment B4. Solid and dashed lines indicate a clockwise and counterclockwise circulation. 
A
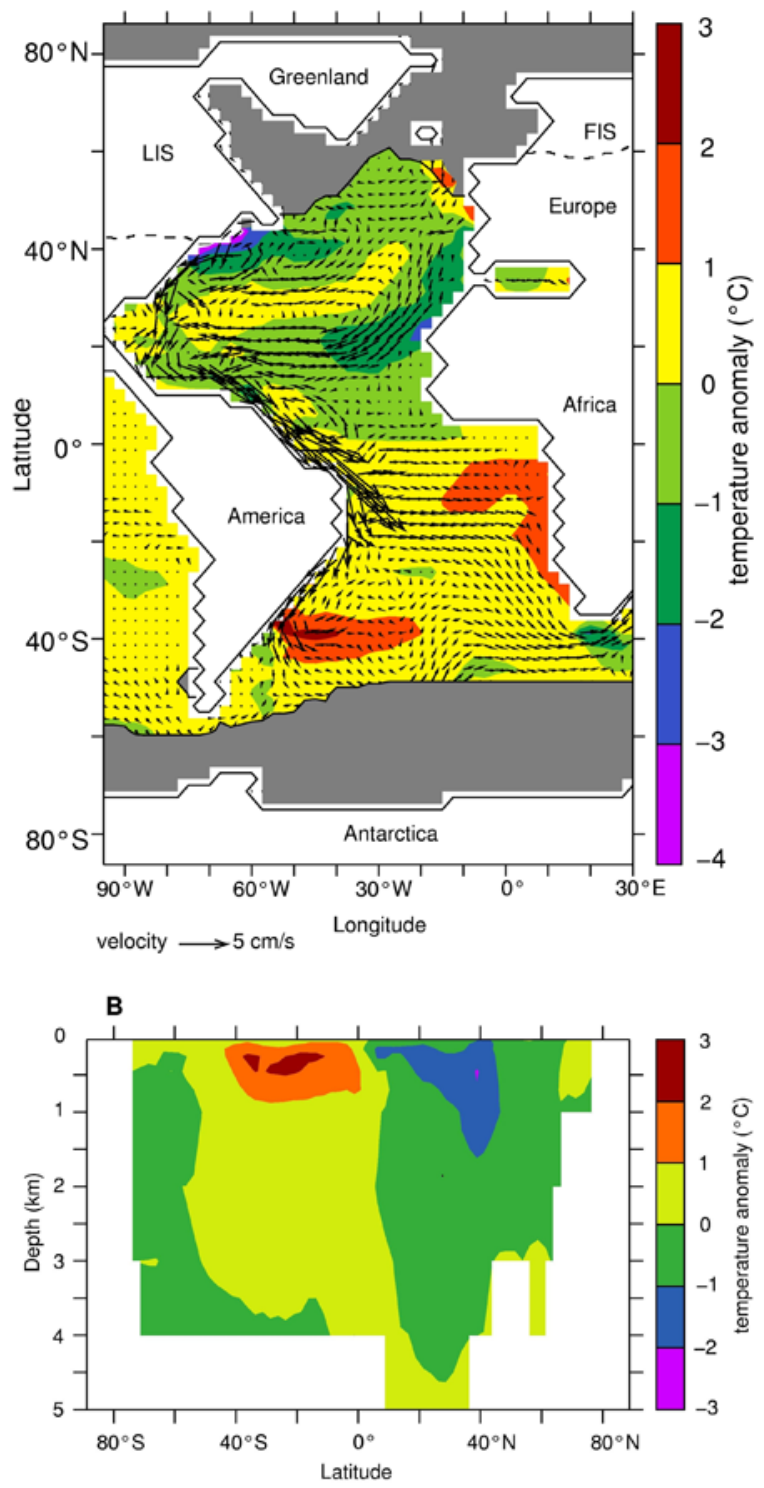

Figure 5. Spatial temperature and horizontal flow field changes in the Atlantic in experiment B2 as a response to the 19 ka MWP between model years 1200 and 1000 in B4. (a) Annual mean SST $\left({ }^{\circ} \mathrm{C}\right)$ differences overlaid with velocity changes $(\mathrm{cm} / \mathrm{s})$. (b) Zonally averaged temperature $\left({ }^{\circ} \mathrm{C}\right)$ differences in the Atlantic basin. The grey shaded area and the black line in Figure 5a show the annual mean $2 \mathrm{~m}$ height ice extent prior to and after the 19 ka MWP. The dashed lines on the continents indicate the LGM extension of the Laurentide (LIS) and Fennoscandian (FIS) Ice Sheets, respectively.

[24] A sea surface cooling up to $4^{\circ} \mathrm{C}$ between $\sim 40^{\circ} \mathrm{N}$ and $50^{\circ} \mathrm{N}$ inshore to North America is caused by a weakening of the Gulf Stream (Figure 5a) as part of the large-scale circulation, accompanied by a reduction of northward oceanic heat transport. In the northeastern Atlantic an anomalous southward advection of cooler surface water is identified, which reflects an intensification of the Portugal Current and the Canary Current. This causes a cooling of $1-3^{\circ} \mathrm{C}$ along the coast off southern Europe and northwest Africa. At around $20^{\circ} \mathrm{N}$ the anomalous flow is transported to the west as part of the southern component of the North Atlantic subtropical gyre. The localized warming offshore Europe between $50^{\circ} \mathrm{N}$ and $60^{\circ} \mathrm{N}$ is linked to convective processes that provide heat from subsurface layers at the fringe of the sea ice cover.

[25] In the South Atlantic, pronounced warming off the Argentinean coast and off the Namibian coast is detected at the end of the 19 ka MWP (Figure 5a). The warming off the Argentinean coast up to $3^{\circ} \mathrm{C}$ is linked to an anomalous southward flow along the coast of South America, which turns to the east at $\sim 40^{\circ} \mathrm{S}$. The warming off Namibia is associated with an anomalous southeastward flow off Angola (Figure 5a).

[26] As warming in B4 proceeds after the $19 \mathrm{ka}$ MWP, North Atlantic cooling caused by reduced northward oceanic heat transport due to the meltwater-induced THC slowdown (Figure 5) turns into a warming above $\sim 3000 \mathrm{~m}$ depth (Figure 6). In particular between $40^{\circ}-50^{\circ} \mathrm{N}$ the downward diffusion of heat as part of the wind driven subtropical Ekman-cell (in conjunction with a weak thermohaline driven cell) (Figure 4a) reaches depths down to $\sim 1000 \mathrm{~m}$, which causes a pronounced temperature increase of up to $4^{\circ} \mathrm{C}$ as detected in the zonal temperature profile (Figure 6). Subsequently, subsurface layers further north in the ice covered North Atlantic are warmed (Figure 3c) by horizontal mixing and weak circulation. This leads to an increasing temperature inversion in the northern

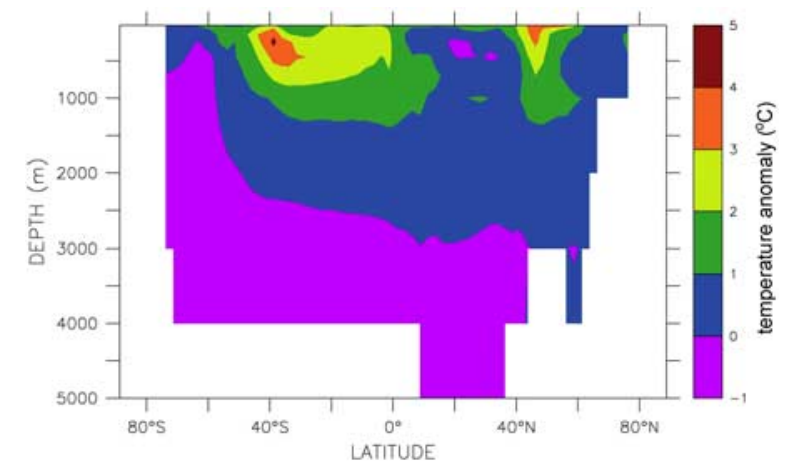

Figure 6. Zonal averaged temperature changes $\left({ }^{\circ} \mathrm{C}\right)$ in the Atlantic basin in experiment B4 at the end of the meltwater event H1a after 4200 model years and the LGM equilibrium state. 
North Atlantic, which causes a destabilization of the vertical stratification and enhanced ventilation in the upper ocean. This process is reinforced as relatively warm and saline water masses from the deeper Atlantic rise to the surface, where they are cooled rapidly by strong surface heat loss to the

\section{A}

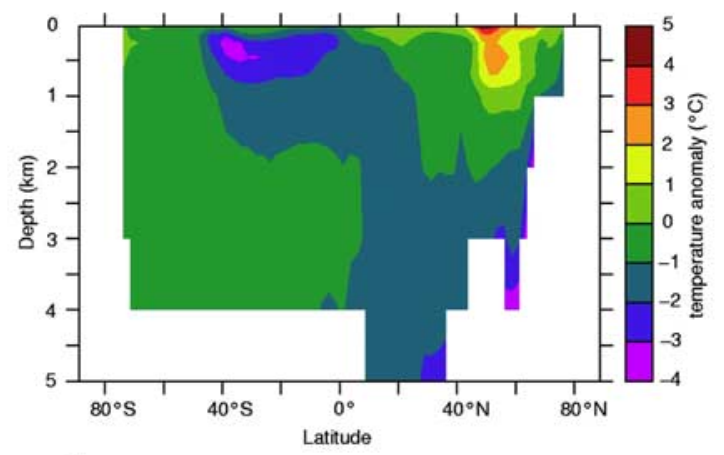

B

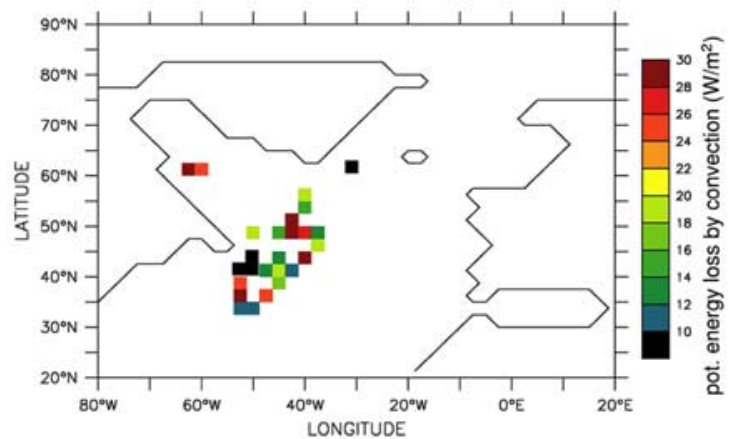

C

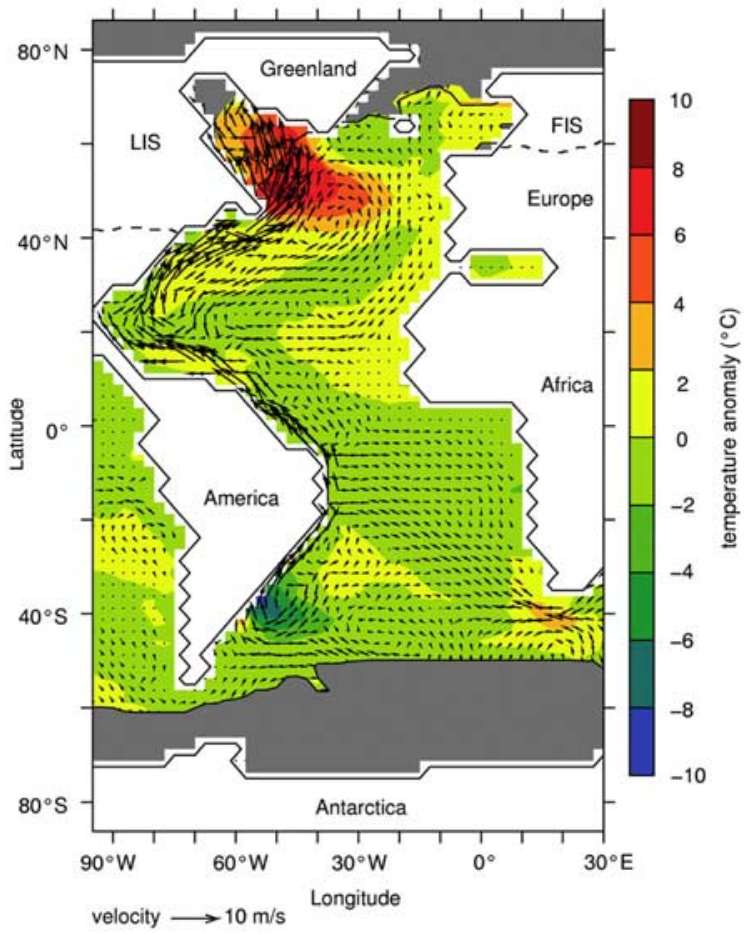

A
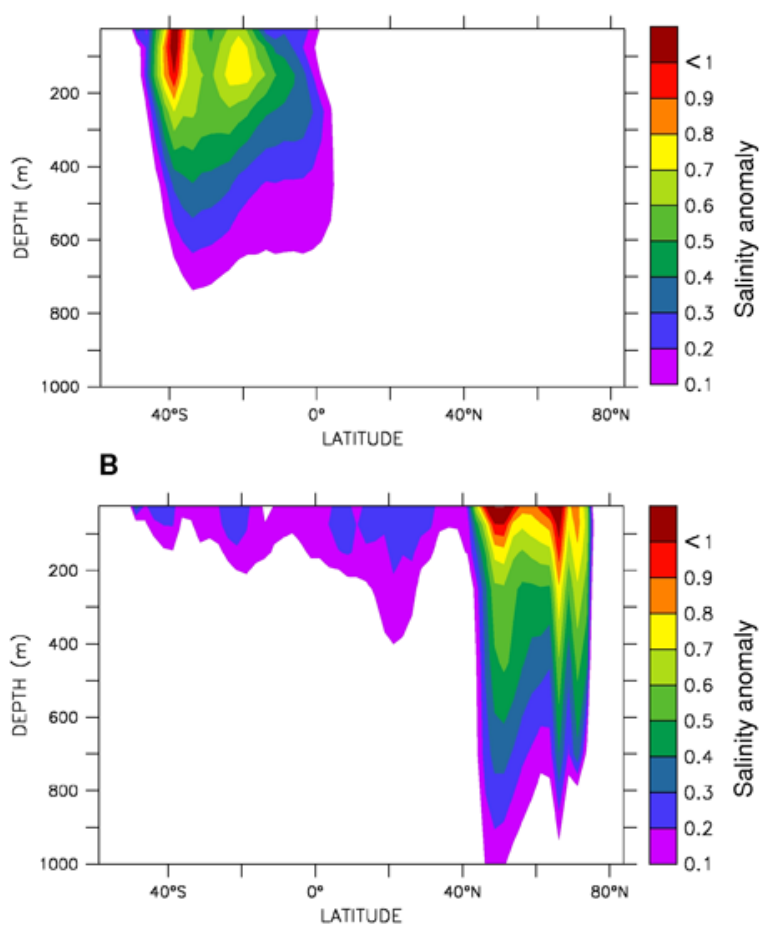

Figure 8. Zonal averaged annual mean salt differences (psu) in the Atlantic between experiment B4 and the LGM after (a) 6000 and (b) 6200 model years. Shown are the positive annually averaged values.

cooler atmosphere. These convective processes are operating locally near the sea ice margin and establish an additional weak and shallow meridional cell at $\sim 60^{\circ} \mathrm{N}$ (Figure $4 \mathrm{~b}$ ), which enhances the salt transport to the high latitude North Atlantic. As a result of intensified ventilation at $\sim 60^{\circ} \mathrm{N}$, northern high latitude subsurface temperatures in the Atlantic decrease after $\sim 4700$ model years, while the warming trend continues at the sea surface (Figure 3c).

Figure 7. Spatial temperature and horizontal flow field differences in the Atlantic as a response to the "kick start" of the THC between model year 6200 and 6000. (a) Annual mean zonally averaged temperature changes in the Atlantic. (b) Changes in the North Atlantic convective activity $\left(\mathrm{W} / \mathrm{m}^{2}\right)$. The black boxes indicate weak and shallow convection sites prior to the THC amplification. (c) Annual mean surface temperature $\left({ }^{\circ} \mathrm{C}\right)$ and velocity $(\mathrm{cm} / \mathrm{s})$ alterations. The grey shaded area and the black line show the annual mean $2 \mathrm{~m}$ height ice extent after 6200 and 6000 model years, respectively. The dashed lines on the continents indicate the LGM extension of the LIS and the FIS. 
[27] After $\sim 5750$ model years the meridional cell at $\sim 60^{\circ} \mathrm{N}$ merges with the wind-driven Ekman-cell (Figure 4c), which gives rise to a stronger NADW cell with cross-equatorial extent (Figures 4c and $4 \mathrm{~d}$ ). This change is characterized by a nearly constant averaged salinity in the South Atlantic between $\sim 5750$ and 6050 model years (Figure 3b), representing the saltiest conditions in the LGM-B/ A interval. The connection of the North and South Atlantic enables a northward advection of excess salt (i.e., surface and near-surface salinities in the subtropical South Atlantic are higher than during the LGM as seen in Figure $3 b$ ) to the northern North Atlantic, where it reinforces convective activity near the sea ice margin (Figure $7 b$ ). The $\sim 300$ a lasting phase is characterized by a gradual intensification of the NADW cell but the NADW export at $30^{\circ} \mathrm{S}$ remains close to zero (Figures $1 \mathrm{~b}$ and 4d). Meanwhile, in spite of the cooling of subsurface water, a strong vertical temperature inversion remains in the northern North Atlantic until $\sim 6000$ model years (Figure 3c). After that the temperature inversion overcomes the salinity stratification in the northern North Atlantic and leads to a rapid invigoration of convection (Figure $7 b$ ), which results in the abrupt amplification of the Atlantic THC (Figures 1b, 4e, and 4f).

[28] Owing to the rapid THC strengthening, a salinity decrease of $\sim 0.35$ is detected in the South Atlantic (Figure 3b), while salinity in the northern Atlantic increases by $\sim 1$ until model year 6200 (Figure 3a). Between 6100 and 6200 model years subsurface temperatures between $850 \mathrm{~m}$ and $1500 \mathrm{~m}$ increase in phase with SST (Figure 3c). After $\sim 6200$ model years the THC amplification reaches its maximum and the respective NADW cell almost occupies the entire Atlantic down to depths of $\sim 4000 \mathrm{~m}$ (Figure 4f).

[29] The THC amplification is characterized by a NADW overshoot of $\sim 5 \mathrm{~Sv}$ which is just half as strong as in experiment B1, where the rapid THC amplification occurred after $\sim 3000$ model years. This difference is linked to a convective feedback involving a vertical temperature relaxation in the northern North Atlantic, which reinforces the THC intensification [cf. Knorr and Lohmann, 2003]. This transient process is more efficient with cooler atmospheric conditions and larger North Atlantic sea ice extent prevailing at the initiation of the THC strengthening in experiment B1. As a consequence of the convective feedback temperatures in large parts of the North Atlantic below 1500 m decrease by more than $1{ }^{\circ} \mathrm{C}$ (Figure $7 \mathrm{a}$ ) and convective activity increases in particular in the Labrador Sea and southeast of Newfoundland (Figure 7b).

[30] Aside from subsurface temperature changes, distinctive SST modifications in the Atlantic are directly linked to the resumption of the THC and accompanying variations in the upper ocean flow field (Figure 7c) and oceanic heat transport. In the upper Atlantic layer, the amplification of the THC is marked by an overall anomalous cross-equatorial northward flow. The maximum northward oceanic heat transport increases to $\sim 1.65 \mathrm{PW}$, which is twice as much as during LGM conditions. A pronounced warming of up to $10^{\circ} \mathrm{C}$ in the Labrador Sea is detected (Figure 7c). In the South Atlantic the strongest cooling occurs off the Argentinean coast, linked to an anomalous westward flow to the region at around $40^{\circ} \mathrm{S}$, which represents the inverse response to that seen during the $19 \mathrm{ka}$ MWP at the same location (Figure 5a). In contrast, SST in the southeastern Atlantic and off South Africa increase up to $3^{\circ} \mathrm{C}$ due to increased westward inflow of relatively warm and salty near-surface and intermediate-depth water masses from the Indian Ocean to the South Atlantic (Figures 7c and 8). This flow response in the surface and middepths of the South Atlantic is favored by the gradual warming and accompanying sea ice retreat in the Southern Ocean, which is linked to a southward shift of the subtropical frontal zone. The resulting transport changes amplify the advection of excess salt (Figure 3b) from the subtropical South Atlantic to the North Atlantic, which additionally amplifies the THC.

[31] Further investigations (not shown) with changed background climate from full glacial to interglacial conditions within 1500 model years (factor of 10 as compared to the B1-B4 scenarios), and experiments with modified wind fields show a similar rapid THC recovery from the "off" mode triggered by deglacial global warming. These results imply that the THC recovery is a relatively robust result in our model setup.

\subsection{Hysteresis Behavior of the THC}

\subsubsection{Stability Dependence on the Background Climate}

[32] In experiment $\mathrm{B} 1$ the overturning strength (Figure 1b) is first slightly weakened before the rapid amplification of the Atlantic THC occurs after $\sim 3000$ model years. This is an interesting feature, since gradual changes in the background climate conditions are intuitively expected to be 


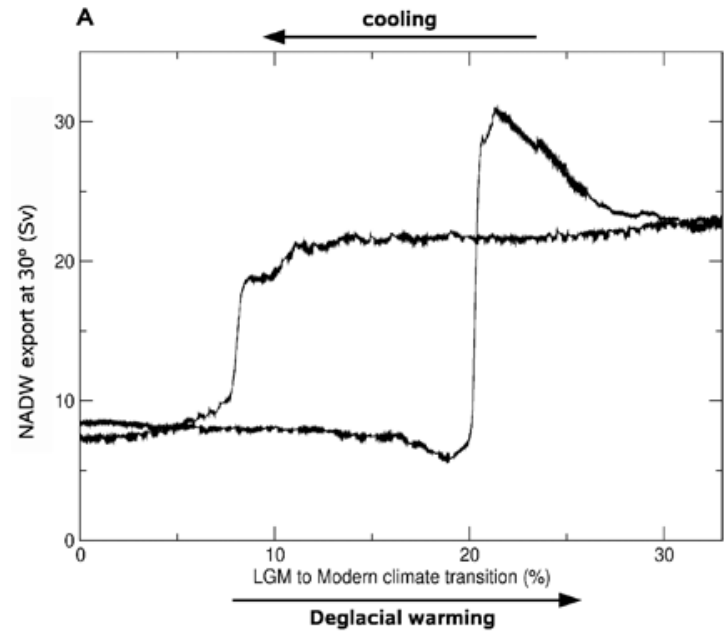

B

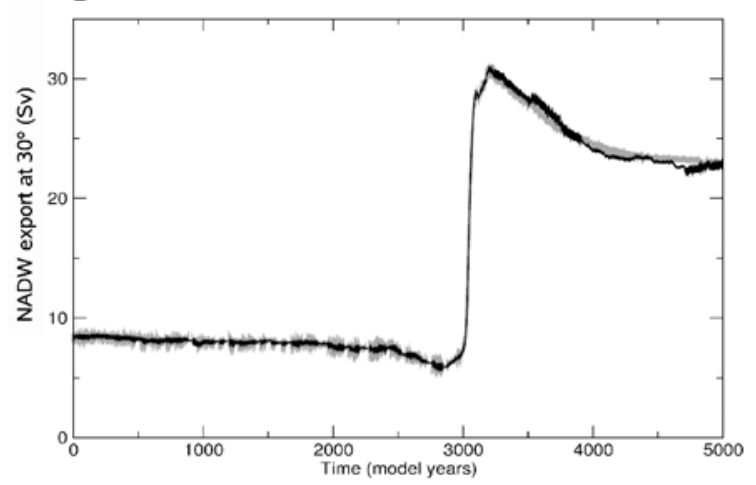

Figure 9. Figure 9a shows the hysteresis loop of the THC with respect to slowly varying climate background conditions. The transition values are given in $\%$ of a full glacial to interglacial transition, derived from equation (2). In Figure 9b, differences in the temporal evolution of the overturning strength between experiment B1 (black curve) and B1_const (thick grey curve) are shown. In B1_const the climate forcing is constant after $21 \%$ (i.e., after 3200 model years) of the deglaciation has been reached. The lower branch in the stability diagram in Figure 9a corresponds to experiment B1 (black curve) in Figure 9b.

linked to an interval of a gradual THC intensification prior to the transition to the stronger THC. This suggests that the mode of the Atlantic THC might be dependent on the initial climate conditions.

[33] The hysteresis curve indeed shows coexistence of multiple THC states in the range of $\sim 8 \%-20 \%$ of the glacial to interglacial transition (Figure 9a). This is the result of an increased northward heat transport in the Atlantic, once the stronger THC mode is established. Therefore a relatively strong background cooling is required to trigger the transition from the stronger THC to the weaker glacial circulation state (Figure 9a). The key for this transition is the insulation effect of growing sea ice in response to cooler surface air temperatures, which reduces the oceanic heat flux to the atmosphere during autumn and winter, weakening the convection particularly in the Labrador Sea (Figure 10). The weakening of convection reduces the oceanic heat transport to the area of deep water formation, which further promotes the formation of sea ice, providing a positive feedback on the weakening of the THC. For transition values less than $8 \%$ the only stable branch is the one with a weaker overturning strength, while the stronger mode of THC represents an exclusive solution beyond a deglacial transition of $20 \%$. This implies that the THC mode is dependent on the initial climate conditions in an interval close to the LGM, but monostable at the LGM and in climates warmer than $\sim 20 \%$ of the glacial to interglacial transition.

[34] The overturning states related to the THC overshoot between $\sim 20 \%-30 \%$ of the deglacial transition, as a consequence of the convective
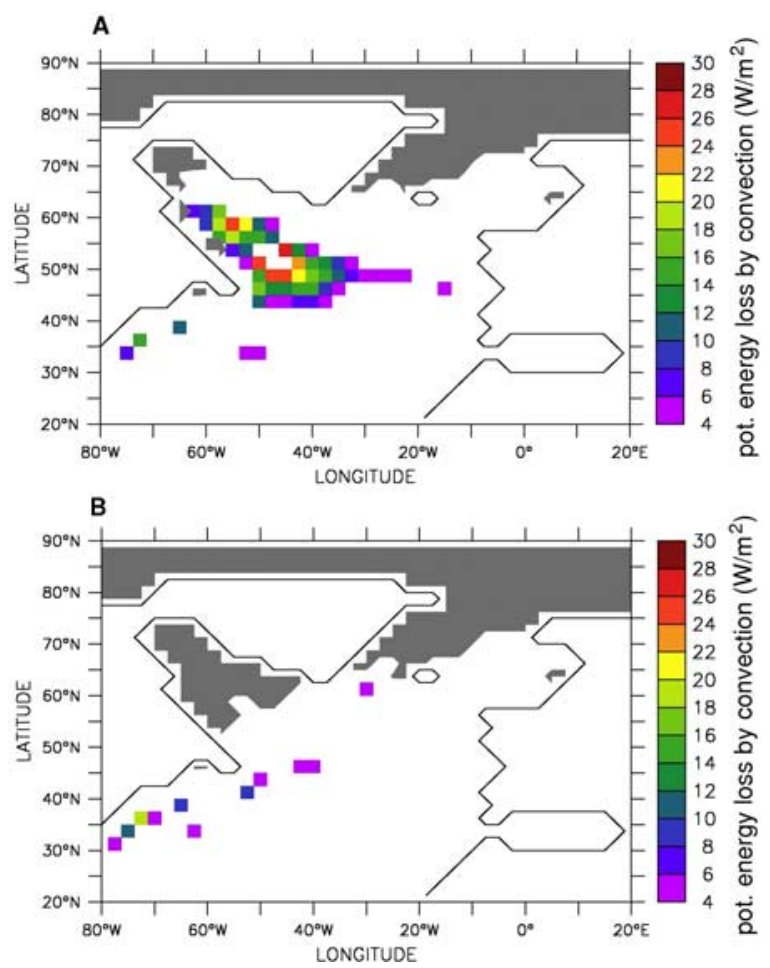

Figure 10. Convection sites, displayed by the convective activity $\left(\mathrm{W} / \mathrm{m}^{2}\right)$ and summer sea ice extent in the northern North Atlantic (a) prior to and (b) after the cooling-induced transition from the stronger $\mathrm{THC}$ to a weaker THC mode. The panels are related to (a) $10 \%$ and (b) $7 \%$ of the total glacial to interglacial transition as shown in the stability curve in Figure 9a. 


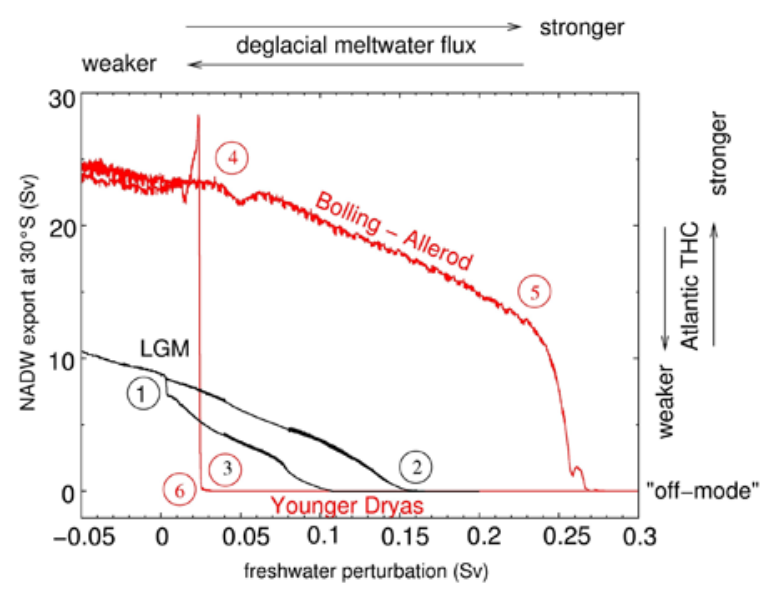

Figure 11. Hysteresis diagrams for the glacial (black curve) [Knorr and Lohmann, 2003] and intensified THC (red curve), overlaid by a potential sequence of deglacial THC changes within a temporal framework of termination I. Starting point is the LGM $\sim 20,000$ a ago (1). This is followed by a transition to the THC "off" mode (2) associated with H1 and potentially the 19 ka MWP. Despite deglacial meltwater fluxes (3), the THC intensification at the $\mathrm{B} / \mathrm{A}$ onset (4) is triggered by deglacial global warming (see Figure 9a). Subsequently, enhanced Northern Hemisphere warming during the B/A increases deglacial meltwater discharge (including MWP-1A), which weakens the THC and terminates the warmest phase of the B/A (5). This cooling in the north might have preconditioned the YD by shifting the climate system into a range where multiple THC states can coexist (see Figure 9a). In conjunction with freshwater discharge to the Arctic/Nordic Seas this might qualitatively explain the onset of the YD. Subsequently, the YD cooling reduces the meltwater flux to the North Atlantic, and the THC is abruptly resumed at the end of the YD (6). The coloring of the numbers corresponds to the position of the climate states to the different hysteresis curves.

feedback involving a vertical temperature relaxation in the northern North Atlantic, do not represent quasi-equilibrium states as shown by experiment B1_const (Figure 9b). The temporal evolution of the overturning strength in B1_const, with constant forcing after $21 \%$ of the deglacial transition has been reached, closely resembles the THC strength in experiment B1 with gradual changing background conditions.

\subsubsection{Stability Dependence on North Atlantic Freshwater Perturbations}

[35] The hysteresis loop (Figure 11), shows that the resumed $\mathrm{THC}$ in $\mathrm{B} 4$ possesses a pronounced bistability for positive freshwater fluxes between $\sim 0.03 \mathrm{~Sv}$ and 0.25 Sv. Starting from experiment
B4 after 8000 model years, the increased freshwater inflow to the North Atlantic reduces salinity, and hence density in the North Atlantic. This weakens the THC and when the freshwater perturbation is stronger than $\sim 0.25 \mathrm{~Sv}$ the THC "off" mode is the only equilibrium solution. To "kickstart" the transition back to the THC "on" mode a reduced freshwater flux anomaly, is required. As a consequence, the intensified THC mode features a stable "off" mode in the interval between $\sim 0.03$ $\mathrm{Sv}$ and $0.25 \mathrm{~Sv}$. In contrast, the glacial THC possesses virtually no stable THC "off" mode, apart from the small interval of positive freshwater fluxes between 0.1 and $0.15 \mathrm{~Sv}$. The different characteristic of the hysteresis loops clearly demonstrate the relative insensitivity of the amplified Atlantic THC to meltwater pulses of less than $\sim 0.25 \mathrm{~Sv}$. The understanding of the existing equilibrium states in the stronger THC mode enables us to estimate the model response to transient freshwater perturbations. Assuming a threshold value of $\sim 0.24 \mathrm{~Sv}$, we can calculate that the intensified THC can potentially cope with a maximum freshwater inflow to the North Atlantic equivalent to a sea level rise of $\sim 40 \mathrm{~m}$ during the $\sim 2000$ a lasting $\mathrm{B} / \mathrm{A}$ oscillation without a THC shutdown. Even in such an extreme scenario, i.e., beyond all estimates of $\mathrm{B} / \mathrm{A}$ sea level rise, a resulting THC weakening of $\sim 50 \%$ would be relatively modest with a persisting overturning flow of more than $10 \mathrm{~Sv}$ (Figure 11).

\section{Discussion}

\subsection{Transition From the LGM to the B/A}

[36] Our results suggest that deglacial global warming leads to an abrupt transition from a stalled THC to a stronger interglacial Atlantic overturning circulation. The transition between these different operation modes of THC can be thought of as an analogy to the transition from a weak Heinrich mode to a stronger B/A circulation mode [e.g., McManus et al., 2004].

[37] The shift from the THC "off" mode to the stronger (B/A-like) flow regime is preconditioned by a decrease of the subsurface temperatures due to an increase in ventilation of the subsurface water in the northern North Atlantic, which enhances the large-scale advection of excess salt from the tropics and the subtropical South Atlantic to the formation areas of NADW. The accumulation of excess salt in the tropics [Schmidt et al., 2004; Weldeab et al., 2006] and the subtrop- 
ical South Atlantic due to a weakened conveyor belt circulation can be explained by a mechanism similar to the thermal seesaw effect [Broecker, 1998; Stocker, 1998]. Large-scale salinity advection in the Atlantic has also been detected in marine sediment core data that exhibit an abrupt decrease of surface salinities in the Caribbean Sea at the initiation of the B/A [Schmidt et al., 2004]. Analysis of marine sediments further south in the western tropical Atlantic however suggests that the termination of high salinity and SST leads the deglacial amplification of the THC by $\sim 500$ a [Weldeab et al., 2006]. This phase matches the detected model interval between the end of the salinity increase in the subtropical South Atlantic at $\sim 5750$ model years and the maximum overturning response at $\sim 6200$ model years, supporting the idea of a deglacial THC reorganization in different phases.

[38] In our deglaciation scenarios B2, B3 and B4 the transition takes place after $\sim 1 / 3$ to $2 / 5$ of the total deglacial warming has occurred (Figure 1b). This is in quantitative agreement with the analysis of ice core data, suggesting that about one-third of the total termination I warming has been achieved before the abrupt warming into the B/A [Alley et al., 2002]. Relatively cold conditions associated with the H1 sequence in the North Atlantic [e.g., Bard et al., 2000], can be attributed to a significantly weaker overturning circulation (Figures $1 \mathrm{~b}$ and $4 \mathrm{a}$ ) and reduced northward heat transport in the Atlantic. This temperature characteristic is also prominent in the sub-surface North Atlantic, which is different to the middepth warming detected by Rühlemann et al. [2004], using a similar model configuration. This shows the importance of the experimental setup (e.g., the strength and especially the duration of the freshwater perturbation), which has been chosen to generate the overturning perturbation. In conjunction with the 19 ka MWP [Clark et al., 2004], the $\mathrm{H} 1$ related freshwater discharges contributed to deglacial warming in the Southern Hemisphere (Figures 3d and 5) superimposed on the general global warming trend. This is in agreement with accentuated warming in the Southern Hemisphere and a reduction of sea ice cover to interglacial conditions between 19-18 ka B.P., as documented by proxy data from the Southern Ocean [Sachs et al., 2001; Shemesh et al., 2002]. The THC recovery after the 19 ka MWP indicates that at this stage of deglaciation the THC mode has been similar to the LGM state, which has virtually no stable THC "off" mode with respect to North Atlantic freshwater perturbations [cf. Prange et al., 2002; Knorr and Lohmann, 2003].
[39] The spatial pattern of the SST changes in response to meltwater pulses during deglaciation shows that the surface regions off Portugal [Bard et al., 2000] and Namibia [Kim et al., 2002] are particularly sensitive to THC weakening and associated cooling and warming, respectively. Additionally, the region off Argentina at $\sim 40^{\circ} \mathrm{S}$ might also prove to be a sensitive region for detecting temperature variations.

[40] Northward cross-equatorial heat transport in the Atlantic is amplified in parallel with the THC resumption after $\sim 6000$ a. As a result, temperatures in the South Atlantic decrease (Figures 3d and 7c), while temperatures in the North Atlantic realm reach almost interglacial values. The spatial temperature differences in the Atlantic associated with the resumption of the THC show that the Labrador Sea might be particularly sensitive to deglacial climate change and significantly influence the climate over Greenland. The large temperature response of up to $10^{\circ} \mathrm{C}$ (Figure 7c), in the Labrador Sea is in the range of the temperature increase documented in Greenland ice cores [e.g., Cuffey et al., 1995; Johnsen et al., 1995]. We suggest that in combination with other effects, e.g., changes in orbital forcing [Milankovitch, 1941], ice albedo [Alley and Clark, 1999] and deglacial changes in atmospheric $\mathrm{CO}_{2}$ [e.g., Toggweiler, 1999; Stephens and Keeling, 2000], the modeled increase in maximum Atlantic northward heat transport from $0.8 \mathrm{PW}$ during the LGM to 1.65 PW in the intensified THC mode might have contributed to the reduction of the Northern Hemisphere ice sheets.

[41] In previous model investigations, the Southern Ocean has been shown to play an active role for the deglacial resumption of the THC at the B/A onset [e.g., Weaver et al., 2003; Knorr and Lohmann, 2004]. The resumption of the THC via Southern Ocean warming requires a longer interval of gradual NADW intensification and increased northward heat transport in the Atlantic before the overturning circulation is abruptly amplified to a stronger THC mode [cf. Knorr and Lohmann, 2003]. The simulations presented here exhibit that gradual global warming can also trigger a rapid amplification of the THC both from the "on" mode (experiment B1, B2) and from the "off" mode (experiment B3 and B4). Until the mode transition the temporal evolution of the THC is dominated by the impact of surface warming or freshening, which tends to weaken the overturning. Hence the impact of deglacial changes in the Southern Ocean on the 
THC amplification in the global warming scenario is limited and the THC resumption is dominated by a convective mechanism in the North Atlantic.

\subsection{Deglacial Changes in the Stability Behavior of the THC}

[42] Results of this study have shown that changes in the stability behavior of the THC can occur in response to changes in the background climate conditions, with the coexistence of multiple THC modes in an interval close to the LGM climate state (Figure 9a). This is in accordance with previous modeling work, suggesting that the THC stability is sensitive with respect to the background climate [Ganopolski and Rahmstorf, 2001; Prange et al., 2002].

[43] Once intensified, the THC is characterized by a distinctive bistability with respect to positive freshwater fluxes to the North Atlantic (Figure 11), indicating a thermal flow regime [Stommel, 1961; Rahmstorf, 1996]. This flow regime is favored by deglacial warming and accompanying sea ice retreat in the Southern Ocean, which is accompanied by a southward shift of the subtropical frontal zone and an enhanced transport of relatively warm and salty water from the Indian Ocean into the South Atlantic (Figures 7c, 8a, and 8b). Deglacial sea surface salinity reconstructions suggest that increased evaporation in the source regions of the warm water route during $\mathrm{H} 1 \mathrm{might}$ even have strengthened this effect [Levi, 2003; Levi et al., 2007]. These alterations might also have played a key role during previous deglaciations, since reconstructions have shown an enhanced exchange between the Indian and Atlantic oceans at the end of the past five glacial periods [Peeters et al., 2004].

[44] The deglaciation was a period with major atmospheric reorganizations, associated with the retreat of the Laurentide and Fennoscandian ice sheets. Therefore alterations in the moisture exchange between the Atlantic and Pacific are likely to have influenced the mode of operation and the sensitivity of the THC [Lohmann, 2003; Romanova et al., 2004; Marsh et al., 2004]. Romanova et al. [2004] used different glacial SST reconstructions such as the CLIMAP [CLIMAP Project Members, 1981], WEINELT [Weinelt et al., 1996] and GLAMAP [Sarnthein et al., 2003] to force the LSG model. By analyzing the hydrological balance in the Atlantic Romanova et al. [2004] found a monotonic relation between the critical freshwater input, necessary to reach the THC "off" mode and the net evaporation in the Atlantic catchment area. The monotonic relation suggests that in a warmer background climate a stronger freshwater perturbation is required to reach the THC "off" mode. The study demonstrated the impact of changes in the hydrological cycle on the THC stability. In this respect the hydrological cycle in the low latitudes might be particularly important, since changes of inter-annual climate variability in the tropical Pacific [Latif et al., 2000; Schmittner and Clement, 2002] can influence the moisture transport across the Panama Isthmus. Furthermore, periods of a weak overturning circulation in the Atlantic are associated with enhanced atmospheric moisture transports across the isthmus, as shown in a coupled atmosphere/ocean model with a comprehensive representation of the hydrological cycle [Lohmann, 2003]. Although in our model approach feedbacks connected with atmospheric dynamics have been neglected, the pronounced hysteresis behavior of the interglacial THC with respect to North Atlantic freshwater perturbations appears to be a robust model characteristic. This has been revealed by a model inter-comparison of 11 intermediate complexity models [Rahmstorf et al., 2005] including the ocean model used in this study, which has shown a qualitatively similar hysteresis behavior for the modern THC in response to freshwater perturbations to the northern North Atlantic. Therefore Rahmstorf et al. [2005] considered it as highly likely that a similar hysteresis behavior would be also found in currently used coupled climate general circulation models. Unfortunately as yet, this has not been tested because of the high computational expense of such comprehensive state of the art models. Since the strong bistability of the interglacial $\mathrm{THC}$ has been identified in a variety of different models [Rahmstorf et al., 2005], our concept with a warming-induced transition from a weak glacial THC with a virtually unstable "off" mode to an intensified interglacial and bistable THC appears to be a relatively robust result. Nonetheless, the fundamental question that remains is whether the glacial THC was monostable or bistable [cf. Prange et al., 2002]. As yet, this question cannot be answered using any existing model, given the uncertainties surrounding our basic understanding of the glacial THC. However, it is suggested from proxy data that the glacial THC "off" mode was unstable given the apparent recovery of the THC following Heinrich events. This would be in agreement with our findings. 


\subsection{Wider Implications}

\subsubsection{Sequence of $B / A, M W P-1 A$, YD, and the Holocene}

[45] A transition from the glacial THC state with an unstable "off" mode to a bistable interglacial THC flow regime as detected in our study implies the potential for a long-term THC weakening in response to sufficiently large meltwater pulses to the North Atlantic (Figure 11). Indeed, the post $\mathrm{B} / \mathrm{A}$ fall-back to cold conditions during the YD, identified in a broad range of proxy data, including ice core records [e.g., Severinghaus and Brook, 1999; Blunier and Brook, 2001] and ocean sediment cores [e.g., Koc et al., 1993] has been associated with a THC shut down [e.g., Broecker et al., 1985]. Surprisingly, the onset of the YD occurred $\sim 1000$ a after MWP-1A, although the THC in current models [e.g. Stocker and Wright, 1991; Saravanan and McWilliams, 1995; Manabe and Stouffer, 1997] responds to freshwater forcing in the order of $0.1 \mathrm{~Sv}$ without delay. In this context the entrainment of considerable amounts of meltwaters associated with MWP-1A in hyperpycnal flows to the Gulf of Mexico [Aharon, 2005], and a routing that links the YD with a Lake Agassiz freshwater pulse routed through the Arctic [Tarasov and Peltier, 2005] have been suggested as possible explanation for the sequence of MWP-1A and YD. Such explanations are sensitive to the location of NADW formation and model configurations such as horizontal and vertical resolution, interactive atmosphere component, advection schemes etc. Our results provide insights into dynamical THC changes during deglacial warming, independent of modifications in, e.g., meltwater distribution and routing changes. According to recent three-dimensional glacial system model results, Tarasov and Peltier [2006] estimated a maximum North American contribution to MWP $1 \mathrm{~A}$ to be $\sim 10.2 \mathrm{~m}$ eustatic equivalent in 600 a. The resulting average meltwater contribution to the North Atlantic would be in the order of $0.19 \mathrm{~Sv}$ which is well within the threshold estimated by our hysteresis analysis of the intensified (interstadial) THC. The second largest deglacial meltwater pulse centered at $\sim 11.3$ ka B.P. was likely then analogous to MWP-1A in that it was not strong enough to interrupt the THC.

[46] Even though the MWP-1A did not trigger a THC shut down and the associated YD directly, we speculate that it probably preconditioned this event by ending the warmest phase of the B/A [Stanford et al., 2006] and shifting the climate system toward cooler conditions where multiple THC states can coexist (Figure 9a). In combination with freshwater discharge to the Arctic/Nordic Seas via the Fram Strait [Tarasov and Peltier, 2006] and a suppression of the stabilizing effect of deepwater flow over the Greenland-Scotland ridge on the THC [Lohmann and Schulz, 2000] it might then explain the onset of the YD. The subsequent reduction of deglacial meltwater inflow, as suggested by reduced snow accumulation over Greenland [Kapsner et al., 1995] and nearly constant ice volume [Lambeck et al., 2002], might then have caused a rapid amplification of the THC. As a consequence a tremendous temperature increase of about $15^{\circ} \mathrm{C}$, as derived from thermally fractionated gases in Greenland ice cores [Severinghaus et al., 1998], has been recorded. This transition at $\sim 11.5$ ka B.P. marks the end of the YD [Severinghaus and Brook, 1999] and the transition to relatively warm conditions that have prevailed throughout the Holocene. A possible sequence of changes in the THC regime and the temporal integration in a deglacial framework is shown in Figure 11.

\subsubsection{Millennial-Scale Climate Variability During the Last Glacial}

[47] It is generally accepted that cold periods in the North Atlantic are associated with reduced NADW formation. Various bipolar "seesaw" models assume that interhemispheric climate changes are triggered by changes in northern freshwater balance. Our results indicate that significant meltwater events can occur during rapid warming events without a THC collapse. Therefore it may be considered that major freshwater anomalies in the climate system might also have occurred in response to THC changes, which is in agreement with previous studies [e.g., Schmittner et al., 2002; Marshall and Koutnik, 2006; Arz et al., 2007].

[48] At present there is no unified theory that can account for an explanation of the large and abrupt millennial-scale climatic fluctuations, associated with the Dansgaard/Oeschger oscillations [Dansgaard et al., 1984] and Heinrich-Dansgaard/ Oeschger tandems [e.g., Bond et al., 1993]. Therefore an approach with rapid reorganizations in the THC being driven by gradual changes in the background climate and the coexistence of multiple THC states in an interval of intermediate climate conditions might help to understand millennialscale climate variability during Marine Isotope 
Stage 3 (MIS3). Especially, because Dansgaard/ Oeschger events occurred during the last glacial cycle, but have been absent during the LGM and the Holocene [Dansgaard et al., 1984]. Such an approach may be considered as an addition or alternative concept to the conventional northern freshwater trigger for rapid reorganizations of the THC.

[49] A potential candidate to generate gradual climate variations on a global scale might be changes in atmospheric $\mathrm{CO}_{2}$ concentrations [Barker and Knorr, 2007]. Atmospheric $\mathrm{CO}_{2}$ variability during MIS3 (as well as on orbital timescales) appears to be intimately related to regional changes around Antarctica and the Southern Ocean [e.g., Siegenthaler et al., 2005; Ahn and Brook, 2007], which indicates the significant potential of the Southern Ocean in affecting atmospheric $\mathrm{CO}_{2}$. During the last glacial atmospheric $\mathrm{CO}_{2}$ increased several thousands of years prior to the rapid warming in Greenland associated with the Dansgaard/Oeschger events 8, 12, 14, and 17. The $\mathrm{CO}_{2}$ increase terminated at the onset of these Greenland warmings [Ahn and Brook, 2007]. The general trend of these glacial $\mathrm{CO}_{2}$ variations (i.e., increase during Heinrich stadials and a decrease in the subsequent interstadial) matches the trend of the required changes in the background climate to trigger a rapid amplification (weakening) of the Atlantic THC at the beginning (end) of an interstadial. Therefore we conjecture that rising $\mathrm{CO}_{2}$ might have contributed to the rapid intensification of the THC after Heinrich events. Moreover recently, the potential role of changes in Southern Ocean Sea ice cover for a THC amplification has been identified for the B/A onset [Knorr and Lohmann, 2003] and it has been speculated that the inherent feedback of a reduced sea-ice cover in the Southern Ocean during Antarctic warming events followed by a delayed onset of deep water formation in the North Atlantic might potentially explain the interhemispheric climate coupling recorded in ice cores [EPICA Community Members, 2006].

\section{Conclusions}

[50] We conclude that the resumption of the Atlantic THC from a weaker overturning circulation during deglaciation can be triggered by deglacial global warming even in the presence of meltwater discharge to the North Atlantic. Superimposed on the deglacial warming trend, freshwater perturbations to the North Atlantic associated with the 19 ka MWP and the H1 result in reduced northward oceanic heat transport, associated with cooling in the north and warming in the south. The THC provides a link between both hemispheres, by "heat storage" in the south [Stocker, 1998] during the sequence of the 19 ka MWP and H1, or "heat piracy" from the South Atlantic [Crowley, 1992], leading to the ACR at the onset of the B/A. The temporal and spatial pattern of interhemispheric climate changes are in agreement with ice core [e.g., Sowers and Bender, 1995; Blunier and Brook, 2001] and ocean sediment records [e.g., Sarnthein et al., 1994; Charles et al., 1996; Bard et al., 2000].

[51] The transition to an interglacial THC mode is preconditioned by a decrease of the subsurface temperatures due to an increase in ventilation of the subsurface water in the northern North Atlantic, which enhances salinity advection from the tropics and the subtropical South Atlantic to the NADW formation regions. The transport of salt to the northern high latitudes gradually erodes the halocline, which enables the vertical temperature inversion to overcome the salinity stratification in the northern North Atlantic. This causes a kick start of vigorous convection and a rapid intensification of the Atlantic THC. The transition is temporarily amplified by a convective feedback in the northern North Atlantic.

[52] As a consequence of deglacial warming and accompanying sea ice retreat in the Southern Ocean the enhanced conveyance of relatively salty surface and intermediate-depth waters from the Indian Ocean provides an additional source of salt to the North Atlantic. This supports the formation of NADW and favors a thermal flow regime. Compared to the weaker glacial THC the amplified THC is relatively insensitive to cumulative North Atlantic fresh water perturbations and possesses a pronounced stable "off" mode in the hysteresis curve for positive freshwater flux anomalies. Our results have also accentuated the possibility that THC changes in the past are not solely linked to freshwater forcing, but also strongly related to gradual changes in background climate. The potential existence of multiple THC modes for intermediate climate states between LGM and Holocene background conditions is linked to an increased northward heat transport in the Atlantic, once the stronger THC mode is established. Therefore a relatively strong background cooling is required to trigger the transition from the stronger THC to the weaker glacial circulation state. 
[53] In summary we find that the succession of climate shifts from the LGM until the Holocene and the interhemispheric temperature evolution can be understood as an interplay of processes operating in both hemispheres. A major agent in mediating between the hemispheres has been the Atlantic THC. Our study emphasizes the possibility that rapid changes in the THC during the last deglaciation and probably also during glacials may be strongly related to gradual changes in the climate background conditions. The concept of a warming-induced (cooling-induced) transition from a weak (strong) THC to a stronger (weaker) THC, with different North Atlantic freshwater hysteresis characteristics, might explain the sequence of events, characterizing the last termination as recorded in proxy data.

[54] In the future, transient deglacial model investigations with comprehensive coupled models of the ocean-atmosphere-cryosphere system are needed to evaluate the importance of the presented concept and the involved mechanisms. Moreover, studies with high resolution climate models are necessary to examine the impact of the warm water route for a deglacial THC strengthening from different initial states of the THC in more detail.

\section{Appendix A: Model Sensitivity to Different Geographical Meltwater Distributions}

[55] It is known that the climate response to freshwater perturbations at high latitudes sensitively depends on the region where the perturbation is released as well as the duration and the amplitude of the perturbation [e.g., Fanning and Weaver, 1997; Meissner and Clark, 2006]. The same perturbation can also cause a different response depending on the climate state itself [e.g., Ganopolski and Rahmstorf, 2001; Meissner et al., 2002; Prange et al., 2002].

[56] To test the robustness of our modeling approach, applying a uniform meltwater distribution in the North Atlantic between $20^{\circ}$ and $50^{\circ} \mathrm{N}$, we have performed a set of three experiments. In experiment STANDARD the freshwater distribution is uniform between $20^{\circ} \mathrm{N}$ and $50^{\circ} \mathrm{N}$. In experiment IRD_BELT the North Atlantic freshwater inflow has been distributed uniformly in the locus of ice rafted detritus sedimentation, the socalled "Ruddiman belt" between $45^{\circ} \mathrm{N}$ and $55^{\circ} \mathrm{N}$ [Ruddiman, 1977]. Furthermore we have conducted experiment MISSIS with a focused fresh-

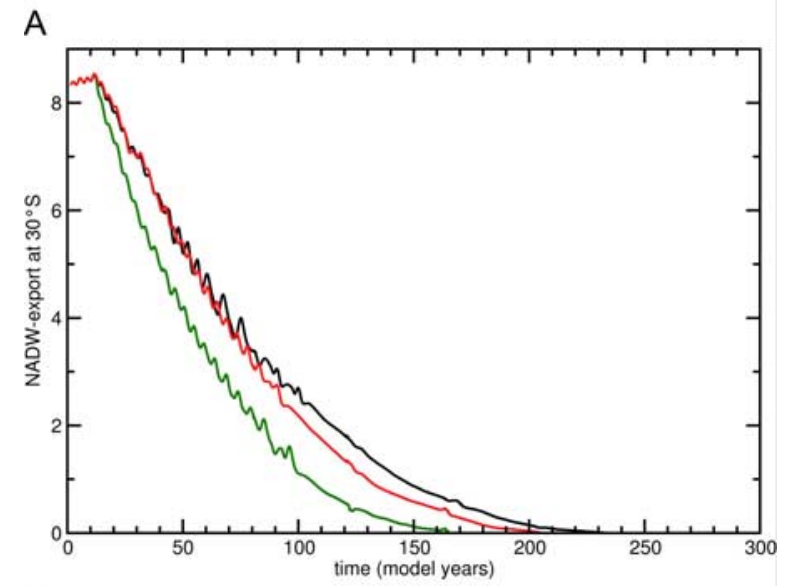

B

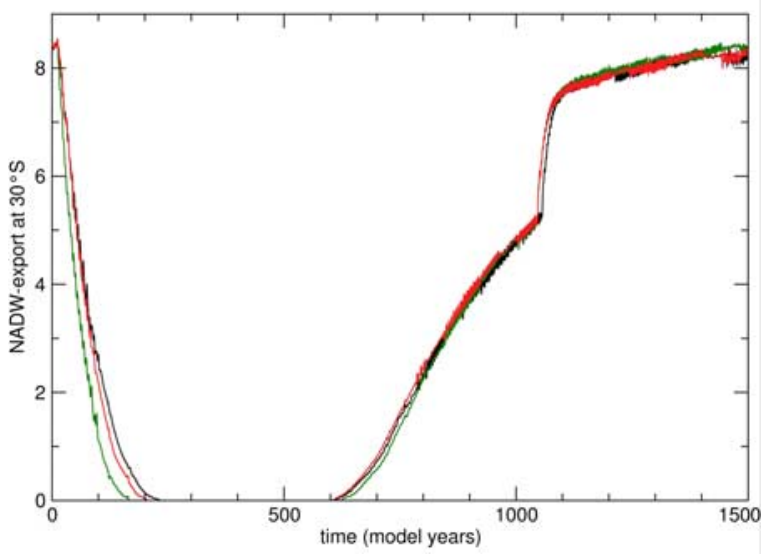

Figure A1. Shown are temporal changes in the NADW outflow of the Atlantic basin at $30^{\circ} \mathrm{S}$ for (a) the first 300 a and (b) the whole experiment. The different experiments are indicated by the different colors: STANDARD (black curve), IRD_BELT (red curve), and MISSIS (green curve).

water outflow via the Mississippi at $\sim 30^{\circ} \mathrm{N}$ [Clark et al., 2001], simulating a point source. All experiments are started from the glacial equilibrium climate state and a freshwater perturbation of $0.25 \mathrm{~Sv}$ is applied after 10 model years lasting for $500 \mathrm{a}$.

[57] After 200 a of freshwater inflow a THC "off" mode without NADW export at $30^{\circ} \mathrm{S}$ is detected in all experiments. The temporal evolution of the NADW export at $30^{\circ} \mathrm{S}$ shows that the fastest transition to the "off" mode occurs in MISSIS, followed by IRD_BELT and STANDARD (Figure A1a). The different model responses can be explained by the effective transport of a relatively concentrated freshwater flux anomaly to the deep water formation sites. In MISSIS the freshwater is efficiently transported to the north via the Gulf Stream. In experi- 
A

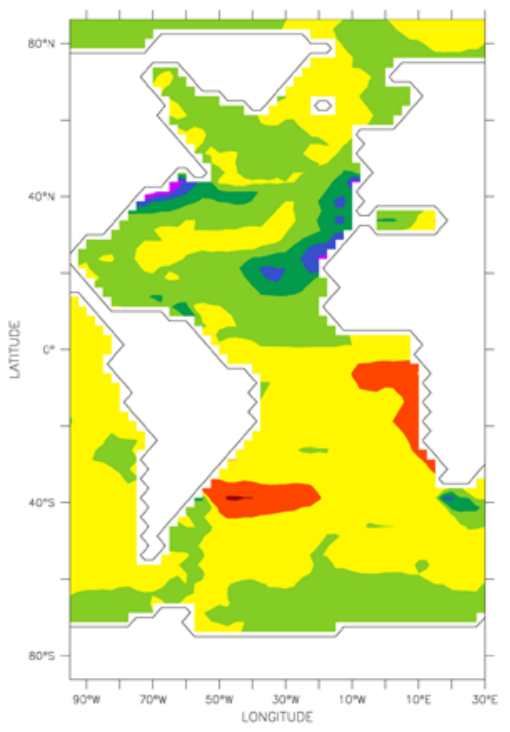

B

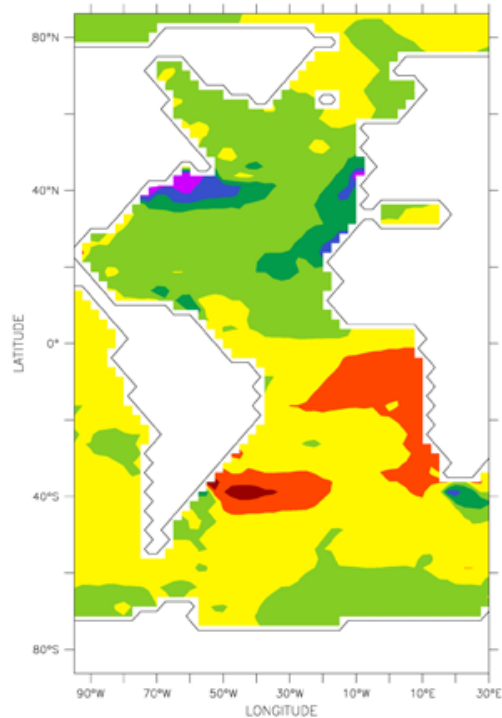

C

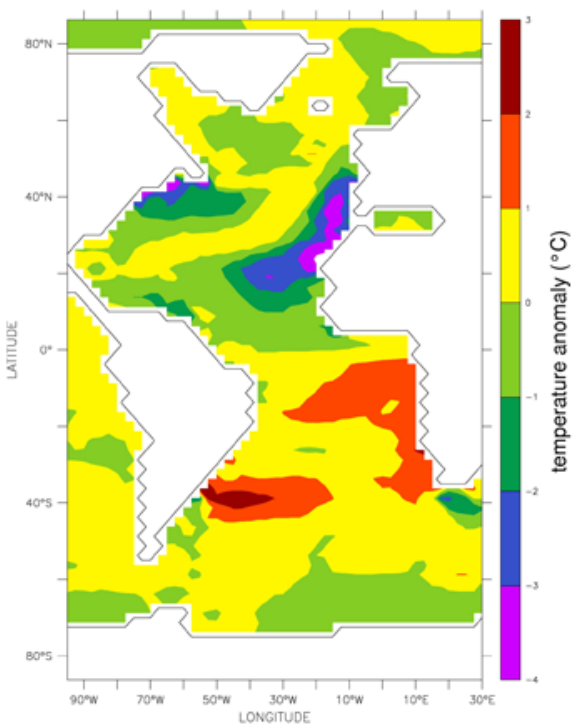

Figure A2. Spatial temperature changes in the Atlantic in (a) experiment STANDARD, (b) experiment MISSIS, and (c) experiment IRD_BELT after 200 a of freshwater inflow to different locations.

ment IRD BELT the concentrated inflow in the latitude belt between $45^{\circ}-55^{\circ} \mathrm{N}$ is also more effective in breaking the overturning flow than in our STANDARD experiment. Therefore we conclude that the chosen meltwater inflow setup as used in our experiments in the manuscript represents a lower estimate of the THC sensitivity.

[58] After the freshwater perturbation is switched off after model year 510, the THC remains in the "off" mode for another century, before the NADW export recovers almost simultaneously in the three different experiments (Figure A1b). After $\sim 1500$ model years the THC gains back its original glacial strength. The very similar temporal evolution of the NADW export after the meltwater inflow vanishes suggests that the processes controlling the THC recovery are relatively independent from the region where the freshwater has been released, i.e., the memory effect is relatively weak.

[59] Furthermore, the spatial temperature pattern in the different experiments when reaching the THC "off" mode after 200 a of freshwater release (Figure A2) are very similar in all three experiments. The strongest cooling related to the THC "off" mode in the North Atlantic occurs along the coast off North America surrounding $\sim 40^{\circ} \mathrm{N}$ and off Southern Europe and northwest Africa. These changes are directly related to variations in the upper ocean flow field and accompanying changes in oceanic heat transports and hence temperature distribution in the Atlantic. The governing mecha- nisms are analogue to the changes described in experiment B4 as response to the 19 ka MWP.

[60] On the basis of these results we infer that the THC changes and the resulting patterns of meridional and zonal temperature variations in the Atlantic, which are presented in the paper, can be considered as relatively robust result in our model setup.

\section{Acknowledgments}

[61] We thank S. Barker, I. Hall, H. Jansen, M. Prange, and C. Rühlemann for fruitful discussions. Furthermore, we would like to acknowledge the insightful and constructive comments of L. C. Skinner and an anonymous reviewer, which significantly helped to improve this study. The work was supported by the BMBF through the DEKLIM project "Climate Transitions."

\section{References}

Aharon, P. (2005), Entrainment of meltwaters in hyperpycnal flows during deglaciation superfloods in the Gulf of Mexico, Earth Planet. Sci. Lett., 241, 260-270.

Ahn, J., and E. J. Brook (2007), Atmospheric $\mathrm{CO}_{2}$ and climate from 65 to 30 ka B.P., Geophys. Res. Lett., 34, L10703, doi:10.1029/2007GL029551.

Alley, R. B., and P. U. Clark (1999), The deglaciation of the northern hemisphere: A global perspective, Annu. Rev. Earth Planet. Sci., 27, 149-182.

Alley, R. B., E. J. Brook, and S. Anandakrishnan (2002), A northern lead in the orbital band: North-south phasing of IceAge events, Quat. Sci. Rev., 21, 431-441.

Arrhenius, S. (1896), On the influence of carbonic acid in the air upon the temperature on the ground, Philos. Mag., 41, 237. 
Arz, H., F. Lamy, A. Ganopolski, N. Nowaczyk, and J. Pätzold (2007), Dominant Northern Hemisphere climate control over millennial-scale glacial sea-level variability, Quat. Sci. Rev., 26, 312-321.

Arz, H. W., J. Patzold, and G. Wefer (1999), The deglacial history of the western tropical Atlantic as inferred from high resolution stable isotope records off northeastern Brazil, Earth Planet. Sci. Lett., 167, 105-117.

Bard, E., F. Rostek, J. L. Turon, and S. Gendreau (2000), Hydrological impact of Heinrich events in the subtropical northeast Atlantic, Science, 289, 1321-1324.

Barker, S., and G. Knorr (2007), Antarctic climate signature in the Greenland ice core record, Proc. Natl. Acad. Sci. USA, 104, 17,278-17,282, doi:10.1073/pnas.0708494104.

Bender, M., T. Sowers, and E. Brook (1997), Gases in ice cores, Proc. Natl. Acad. Sci. U. S. A., 94, 8343-8349.

Bender, M. L., B. Malaize, J. Orchardo, T. Sowers, and J. Jouzel (1999), High precision correlations of Greenland and Antarctic ice core records over the last $100 \mathrm{kyr}$, in $\mathrm{Me}$ chanisms of Global Climate Change at Millennial Time Scales, Geophys. Monogr. Ser., vol. 112, edited by P. U. Clark, R. S. Webb, and L. D. Keigwin, pp. 149-164, AGU, Washington, D. C.

Blunier, T., and E. J. Brook (2001), Timing of millennial-scale climate change in Antarctica and Greenland during the last glacial period, Science, 291, 109-112.

Blunier, T., J. Schwander, B. Stauffer, T. Stocker, A. Dällenbach, A. Indermühle, J. Tschumi, J. Chappellaz, D. Raynaud, and J.-M. Barnola (1997), Timing of temperature variations during the last deglaciation in Antarctica and the atmospheric $\mathrm{CO}_{2}$ increase with respect to the Younger Dryas event, Geophys. Res. Lett., 24, 2683-2686.

Bond, G., W. Broecker, S. Johnsen, J. McManus, L. Labeyrie, J. Jouzel, and G. Bonani (1993), Correlations between climate records from North Atlantic sediments and Greenland ice, Nature, 364, 143-147.

Broecker, W. S. (1998), Paleocean circulation during the last deglaciation: A bipolar seesaw?, Paleoceanography, 13, 119-121.

Broecker, W. S., D. M. Peteet, and D. Rind (1985), Does the ocean-atmosphere system have more than one stable mode of operation?, Nature, 315, 21-25.

Charles, C. D., J. Lynch-Stieglitz, U. S. Ninnemann, and R. G. Fairbanks (1996), Climate connections between the hemisphere revealed by deep sea sediment core ice core correlations, Earth Planet. Sci. Lett., 142, 19-27.

Clark, P. U., S. J. Marshall, G. K. C. Clarke, S. W. Hostetler, J. M. Licciardi, and J. T. Teller (2001), Freshwater forcing of abrupt climate change during the last glaciation, Science, 13, $283-287$

Clark, P. U., A. M. McCabe, A. C. Mix, and A. J. Weaver (2004), Rapid rise of sea level 19,000 years ago and its global implications, Science, 304, 1141-1144.

CLIMAP Project Members (1981), Seasonal Reconstructions of the Earth Surface at the Last Glacial Maximum, Map Chart Ser., vol. MC-36, 18 maps, Geol. Soc. of Am., Boulder, Colo.

Crowley, T. J. (1992), North Atlantic deep water cools the southern hemisphere, Paleoceanography, 7, 489-497.

Cuffey, K. M., G. D. Clow, R. B. Alley, M. Stuiver, E. D. Waddington, and R. W. Saltus (1995), Large Arctic temperature change at the Wisconsin-Holocene glacial transition, Science, 270, 455-458.

Dansgaard, W., S. J. Johnsen, H. B. Clausen, D. Dahl-Jensen, N. Gundestrup, C. U. Hammer, and H. Oeschger (1984), North Atlantic climatic oscillations revealed by deep Green- land ice cores, in Climate Processes and Climate Sensitivity, Geophys. Monogr. Ser., vol. 29, edited by J. E. Hansen and T. Takahashi, pp. 288-298, AGU, Washington, D. C.

Dowdeswell, J. A., M. A. Maslin, J. T. Andrews, and I. N. McCave (1995), Iceberg production, debris rafting, and the extent and thickness of Heinrich layers (H-1, H-2) in North Atlantic sediments, Geology, 23, 301-304.

EPICA Community Members (2006), One-to-one coupling of glacial climate variability in Greenland and Antarctica, Nature, 444, 195-198, doi:10.1038/nature05301.

Fairbanks, R. G. (1989), A 17,000-year glacio-eustatic sealevel record-Influence of glacial melting rates on the Younger Dryas event and deep-ocean circulation, Nature, 342, 637-642.

Fanning, A. F., and A. J. Weaver (1997), Temporal-geographical meltwater influences on the North Atlantic Conveyor: Implications for the Younger Dryas, Paleoceanography, 12(2), 307-320.

Ganopolski, A., and S. Rahmstorf (2001), Rapid changes of glacial climate simulated in a coupled climate model, Nature, 409, $153-158$.

Gherardi, J. M., L. Labeyrie, J. F. McManus, R. Francois, L. C. Skinner, and E. Cortijo (2005), Evidence from the Northeastern Atlantic basin for variability in the rate of the meridional overturning circulation through the last deglaciation, Earth Planet. Sci. Lett., 240, 710-723.

Gordon, A. L. (1986), Inter-ocean exchange of thermocline water, J. Geophys. Res., 91, 5037-5046.

Gordon, A. L., R. F. Weiss, W. M. Smethie, and M. J. Warner (1992), Thermocline and intermediate water communication between the South Atlantic and Indian Oceans, J. Geophys. Res., 97, 7223-7240.

Grootes, P., M. Stuiver, J. W. C. White, S. J. Johnsen, and J. Jouzel (1993), Comparison of oxygen isotope records from GISP2 Greenland ice cores, Nature, 366, $552-554$.

Hanebuth, T., K. Stattegger, and P. M. Grootes (2000), Rapid flooding of the Sunda Shelf: A late-glacial sea-level record, Science, 288, 1033-1035.

Heinrich, H. (1988), Origin and consequences of cyclic ice rafting in the northeast Atlantic Ocean during the past 130,000 tears, Quat. Res., 29, 142-152.

Hemming, S. R. (2004), Heinrich events: Massive late Pleistocene detritus layers of the North Atlantic and their global climate imprint, Rev. Geophys., 42, RG1005, doi:10.1029/ 2003RG000128.

Imbrie, J., and J. Z. Imbrie (1980), Modeling the climatic response to orbital variations, Science, 207, 943-953.

Johnsen, S. J., D. Dahljensen, W. Dansgaard, and N. Gundestrup (1995), Greenland paleotemperatures derived from grip bore hole temperature and ice core isotope profiles, Tellus, Ser. B, 47, 624-629.

Kapsner, W. R., R. B. Alley, C. A. Shuman, S. Anandakrishnan, and P. Grootes (1995), Dominant influence of atmospheric circulation on snow accumulation in Greenland over the past 18,000 years, Nature, 373, 52-54.

Kim, J. H., R. R. Schneider, P. J. Muller, and G. Wefer (2002), Interhemispheric comparison of deglacial sea-surface temperature patterns in Atlantic eastern boundary currents, Earth Planet. Sci. Lett., 203, 779-780.

Knorr, G., and G. Lohmann (2003), Southern Ocean origin for the resumption of Atlantic thermohaline circulation during deglaciation, Nature, 424, 532-536.

Knorr, G., and G. Lohmann (2004), The Southern Ocean as the flywheel of the oceanic conveyor belt circulation, Pages News, 12, 11-13. 
Knutz, P. C., R. Zahn, and I. R. Hall (2007), Centennial-scale variability of the British Ice Sheet: Implications for climate forcing and Atlantic meridional overturning circulation during the last deglaciation, Paleoceanography, 22, PA1207, doi:10.1029/2006PA001298.

Koc, N., E. Jansen, and H. Haflidason (1993), Paleoceanographic reconstructions of surface ocean conditions in the Greenland, Iceland and Norwegian Seas through the last 14 ka based on diatoms, Quat. Sci. Rev., 12, 115-140.

Lambeck, K., Y. Yokoyama, and T. Purcell (2002), Into and out of the Last Glacial Maximum: Sea-level change during Oxygen Isotope Stages 3 and 2, Quat. Sci. Rev., 21, $343-$ 360, doi:10.1016/S0277-379 (01)00071-3.

Latif, M., E. Roeckner, U. Mikolajewicz, and R. Voss (2000), Tropical stabilization of the thermohaline circulation in a Greenhouse warming simulation, J. Clim., 13, 1809-1813.

Levi, C. (2003), Etude des variations climatiques de la zone Indo-Pacifique: Rôle des basses latitudes dans la variabilité millénaire du climat, Ph.D. thesis, 153 pp., Univ. Paris XI, Orsay, France.

Levi, C., L. Labeyrie, F. Bassinot, F. Guichard, E. Cortijo, C. Waelbroeck, N. Caillon, J. Duprat, T. de Garidel-Thoron, and H. Elderfield (2007), Low-latitude hydrological cycle and rapid climate changes during the last deglaciation, Geochem. Geophys. Geosyst., 8, Q05N12, doi:10.1029/ 2006GC001514.

Lohmann, G. (1998), The influence of a near-bottom transport parameterization on the sensitivity of the thermohaline circulation, J. Phys. Oceanogr., 28, 2095-2103.

Lohmann, G. (2003), Atmospheric and oceanic freshwater transport during weak Atlantic overturning circulation, Tellus, Ser. A, 55, 438-449.

Lohmann, G., and R. Gerdes (1998), Sea ice effects on the sensitivity of the thermohaline circulation in simplified atmosphere-ocean-sea ice models, J. Clim., 11, 2789-2803.

Lohmann, G., and S. Lorenz (2000), On the hydrological cycle under paleoclimatic conditions as derived from AGCM simulations, J. Geophys. Res., 105, 17,417-17,436.

Lohmann, G., and M. Schulz (2000), Reconciling Bølling warmth with peak deglacial meltwater discharge, Paleoceanography, 15, 537-540.

Lynch-Stieglitz, J., et al. (2007), Atlantic meridional overturning circulation during the Last Glacial Maximum, Science, 316, 66-69, doi:10.1126/science.1137127.

Macdonald, A. M., and C. Wunsch (1996), An estimate of global ocean circulation and heat fluxes, Nature, 382, 436-439.

Maier-Reimer, E., U. Mikolajewicz, and K. Hasselmann (1993), Mean circulation of the Hamburg LSG OGCM and its sensitivity to the thermohaline surface forcing, J. Phys. Oceanogr., 23, 731-757.

Manabe, S., and R. J. Stouffer (1997), Coupled oceanatmosphere model response to freshwater input: Comparison to Younger Dryas event, Paleoceanography, 12, 321-336.

Marsh, R., A. Yool, T. M. Lenton, M. Y. Gulamali, N. R. Edwards, J. G. Shepherd, M. Krznaric, S. Newhouse, and S. J. Cox (2004), Bistability of the thermohaline circulation identified through comprehensive 2-parameter sweeps of an efficient climate model, Clim. Dyn., 23, 761-777.

Marshall, S. J., and M. R. Koutnik (2006), Ice sheet action versus reaction: Distinguishing between Heinrich events and Dansgaard-Oeschger cycles in the North Atlantic, Paleoceanography, 21, PA2021, doi:10.1029/2005PA001247.

McCabe, A. M., and P. U. Clark (1998), Ice-sheet variability around the north Atlantic Ocean during the last deglaciation, Nature, 392, 373-377.
McManus, J. F., R. Francois, J. M. Gherardi, L. D. Keigwin, and S. Brown-Leger (2004), Collapse and rapid resumption of Atlantic meridional circulation linked to deglacial climate changes, Nature, 428, 834-837.

Meissner, K. J., and P. U. Clark (2006), Impact of floods versus routing events on the thermohaline circulation, Geophys. Res. Lett., 33, L15704, doi:10.1029/2006GL026705.

Meissner, K. J., A. Schmittner, E. C. Wiebe, and A. J. Weaver (2002), Simulations of Heinrich Events in a coupled oceanatmosphere-sea ice model, Geophys. Res. Lett., 29(14), 1671, doi:10.1029/2001GL013514.

Milankovitch, M. (1941), Kanon der Erdbestrahlung, R. Serbian Acad. Spec. Publ. 132, Sect. Math. Natl. Sci., Beograd.

Peeters, F. J. C., R. Acheson, G. J. A. Brummer, W. de Ruijter, R. R. Schneider, G. Ganssen, E. Ufkes, and D. Kroon (2004), Vigorous exchange between the Indian and Atlantic oceans at the end of the past five glacial periods, Nature, $430,661-665$.

Peltier, W. R., and R. G. Fairbanks (2006), Global glacial ice volume and Last Glacial Maximum duration from an extended Barbados sea level record, Quat. Sci. Rev, doi:10.1016/j.quascirev.2006.04.010.

Petit, J. R., et al. (1999), Climate and atmospheric history of the past 420,000 years from the Vostok ice core, Antarctica, Nature, 399, 429-436.

Prange, M., V. Romanova, and G. Lohmann (2002), The glacial thermohaline circulation: Stable or unstable?, Geophys. Res. Lett., 29(21), 2028, doi:10.1029/2002GL015337.

Prange, M., G. Lohmann, and A. Paul (2003), Influence of vertical mixing on the thermohaline hysteresis: Analyses of an OGCM, J. Phys. Oceanogr., 33, 1707-1721.

Rahmstorf, S. (1995), Bifurcations of the Atlantic thermohaline circulation in response to changes in the hydrological cycle, Nature, 378, 145-149.

Rahmstorf, S. (1996), On the freshwater forcing and transport of the Atlantic thermohaline circulation, Clim. Dyn., 12, 799-811.

Rahmstorf, S., and J. Willebrand (1995), The role of temperature feedback in stabilising the thermohaline circulation, J. Phys. Oceanogr., 25, 787-805.

Rahmstorf, S., et al. (2005), Thermohaline circulation hysteresis: A model intercomparison, Geophys. Res. Lett., 32, L23605, doi:10.1029/2005GL023655.

Roeckner, E., et al. (1992), Simulation of the present-day climate with the ECHAM model: Impact of model physics and resolution, 171 pp., Max-Planck-Inst. für Meteorol., Hamburg, Germany.

Romanova, V., M. Prange, and G. Lohmann (2004), Stability of the glacial thermohaline circulation and its dependence on the background hydrological cycle, Clim. Dyn., 22, $527-$ 538.

Ruddiman, W. F. (1977), Late Quaternary deposition of icerafted sand in the subpolar North Atlantic (lat. $40^{\circ}$ to $65^{\circ} \mathrm{N}$ ), Geol. Soc. Am. Bull., 88, 1813-1827.

Rühlemann, C., S. Mulitza, G. Lohmann, A. Paul, M. Prange, and G. Wefer (2004), Intermediate depth warming in the tropical Atlantic related to weakened thermohaline circulation: Combining paleoclimate data and modeling results for the last deglaciation, Paleoceanography, 19, PA1025, doi:10.1029/2003PA000948.

Sachs, J. P., R. F. Anderson, and S. J. Lehman (2001), Glacial surface temperatures of the southeast Atlantic Ocean, Science, 293, 2077-2079.

Saravanan, R., and J. C. McWilliams (1995), Multiple equilibria, natural variability, and climate transitions in an idealized ocean-atmosphere model, J. Clim., 8, 2296-2323. 
Sarnthein, M., K. Winn, S. J. A. Jung, J.-C. Duplessy, L. Labeyrie, H. Erlenkeuser, and G. Ganssen (1994), Changes in east Atlantic deepwater circulation over the last 30,000 years: Eight time slice reconstructions, Paleoceanography, 9(2), 209-268.

Sarnthein, M., R. Gersonde, S. Niebler, U. Pflaumann, R. Spielhagen, J. Thiede, G. Wefer, and M. Weinelt (2003), Overview of Glacial Atlantic Ocean Mapping (GLAMAP 2000), Paleoceanography, 18(2), 1030, doi:10.1029/ 2002PA000769.

Schäfer-Neth, C., and A. Paul (2001), Circulation of the glacial Atlantic: A synthesis of global and regional modeling, in The Northern North Atlantic: A Changing Environment, edited by P. Schäfer et al., pp. 446-462, Springer, Berlin.

Schmidt, M. W., H. J. Spero, and D. W. Lea (2004), Links between salinity variation in the Caribbean and North Atlantic thermohaline circulation, Nature, 428, 160-163.

Schmittner, A., and A. C. Clement (2002), Sensitivity of the thermohaline circulation to tropical and high latitude freshwater forcing during the last glacial-interglacial cycle, $\mathrm{Pa}$ leoceanography, 17(2), 1017, doi:10.1029/2000PA000591.

Schmittner, A., M. Yoshimori, and A. J. Weaver (2002), Instability of glacial climate in a model of the ocean-atmosphere-cryosphere system, Science, 295, 1489-1493.

Severinghaus, J. P., and E. J. Brook (1999), Abrupt climate change at the end of the last glacial period inferred from trapped air in polar ice, Science, 286, 930-934.

Severinghaus, J. P., T. Sowers, E. J. Brook, R. B. Alley, and M. L. Bender (1998), Timing of abrupt climate change at the end of the Younger Dryas interval from thermally fractionated gases in polar ice, Nature, 391, 141-146.

Shackleton, N. J. (2000), The 100,000-year ice-age cycle identified and found to lag temperature, carbon dioxide, and orbital eccentricity, Science, 289, 1897-1902.

Shemesh, A., D. Hodell, X. Crosta, S. Kanfoush, C. Charles, and T. Guilderson (2002), Sequence of events during the last deglaciation in Southern Ocean sediments and Antarctic ice cores, Paleoceanography, 17(4), 1056, doi:10.1029/ 2000PA000599.

Siegenthaler, U., et al. (2005), Stable carbon cycle-climate relationship during the late Pleistocene, Science, 310, $1313-1317$.

Skinner, L. C., and N. J. Shackleton (2004), Rapid transient changes in northeast Atlantic deep water ventilation age across Termination I, Paleoceanography, 19, PA2005, doi:10.1029/2003PA000983.

Sowers, T., and M. Bender (1995), Climate records covering the last deglaciation, Science, 269, 210-214.

Stanford, J. D., E. J. Rohling, S. E. Hunter, A. P. Roberts, S. O. Rasmussen, E. Bard, J. McManus, and R. G. Fairbanks (2006), Timing of meltwater pulse 1a and climate responses to meltwater injections, Paleoceanography, 21, PA4103, doi:10.1029/2006PA001340.

Stephens, B. B., and R. F. Keeling (2000), The influence of Antarctic sea ice on glacial-interglacial $\mathrm{CO}_{2}$ variations, Nature, 404, 171-174.

Stocker, T. F. (1998), The seesaw effect, Science, 282, 61-62.

Stocker, T. F., and D. G. Wright (1991), Rapid transitions of the ocean's deep circulation induced by changes in surface water fluxes, Nature, 351, 729-732.

Stommel, H. (1961), Thermohaline convection with two stable regimes of flow, Tellus, 13, 224-230.

Tarasov, L., and W. R. Peltier (2005), Arctic freshwater forcing of the Younger Dryas cold reversal, Nature, 435, 662-665, doi:10.1016/j.quascirev.2005.12.006.

Tarasov, L., and W. R. Peltier (2006), A calibrated deglacial drainage chronology for the North American continent: Evidence of an Arctic trigger for the Younger Dryas, Quat. Sci. Rev., 25, 659-688.

Toggweiler, J. R. (1999), Variation of atmospheric $\mathrm{CO}_{2}$ by ventilation of the ocean's deepest water, Paleoceanography, $14,571-588$

Waelbroeck, C., J. C. Duplessy, E. Michel, L. Labeyrie, D. Paillard, and J. Duprat (2001), The timing of the last deglaciation in North Atlantic climate records, Nature, 412, 724-727, doi: $10.1038 / 35089060$.

Weaver, A. J., O. A. Saenko, P. U. Clark, and J. X. Mitrovica (2003), Meltwater pulse 1A from Antarctica as a trigger of the Bolling-Allerod warm interval, Science, 299, 17091713.

Weinelt, M., M. Sarnthein, U. Pflaumann, H. Schulz, S. Jung, and H. Erlenkeuser (1996), Ice-free Nordic Seas during the Last Glacial Maximum? Potential sites of deepwater formation, Palaeoclimates, 1, 283-309.

Weldeab, S., R. R. Schneider, and M. Kolling (2006), Deglacial sea surface temperature and salinity increase in the western tropical Atlantic in synchrony with high latitude climate instabilities, Earth Planet. Sci. Lett., 241, 699-706. 